\title{
Investment-Cash Flow Sensitivity Under Changing Information
}

\section{Asymmetry}

Jaideep Chowdhury

Dissertation submitted to the faculty of the Virginia Polytechnic Institute and State University in partial fulfillment of the requirements for the degree of

Doctor of Philosophy

In

Business, Finance

Raman Kumar, Co-Chair

Dilip K. Shome, Co-Chair

Arthur J. Keown

Ozgur S. Ince

July $12^{\text {th }}, 2011$.

Blacksburg, VA

Keywords: Information asymmetry, Investment Cash Flow Sensitivity

Copyright: Jaideep Chowdhury 


\title{
Investment-Cash Flow Sensitivity Under Changing Information
}

\section{Asymmetry}

\author{
Jaideep Chowdhury
}

\begin{abstract}
Most studies of the investment-cash flow sensitivity hypothesis in the literature compare estimates of the sensitivity coefficients from cross sectional regressions across groups of firms classified into more or less financially constrained groups based on some measure of perceived financial constraint. These studies report conflicting results depending on the classification scheme used to stratify the sample. They have been criticized on conceptual and methodological grounds. In this study we mitigate some of these problems reported in the literature by using the insights from Cleary, Povel and Raith (2007) in a new research design. We test for the significances of the changes in the investment-cash flow sensitivity, in a time-series rather than cross sectional framework, for the same set of firms surrounding an exogenous shock to the firms' information asymmetry. The CPR (2007) model predicts an unambiguous increase (decrease) in investment-cash flow sensitivity when information asymmetry of the firm increases (decreases). Further, by examining the differences in the sensitivity coefficients we expect some of the biases in the coefficient from measurement errors in Q to cancel out. The two events we study are (i) the implementation of SOX which is expected to decrease information asymmetry from improved and increased disclosure and (ii) the deregulation of industries which is expected to increase information asymmetry largely from the lifting of price controls and entry barriers. We report that information asymmetry decreases following SOX and that there is a commensurate decrease in the investment-cash flow sensitivity, pre- to post SOX. The hypothesis that a greater change in investment cash flow sensitivity is associated with a greater change in information
\end{abstract}


asymmetry is only weakly supported by the data. We also report that information asymmetry increases following deregulation with a commensurate increase in investment cash flow sensitivity, pre to post deregulation. The hypothesis of a greater increase in the sensitivity for subsamples with a greater increase in information asymmetry is not supported by the data. Overall, however, the study supports the investment-cash flow sensitivity hypothesis using a research design that corrects for some of the problems identified in the existing literature on the hypothesis. 


\section{Acknowledgement}

I am greatly indebted to my advisers Professor Raman Kumar and Professor Dilip Shome for their patience, help and continuous support. It has been a great learning experience for me. They have taught me so many things, not only just Finance and Econometrics.

I also benefited from the other members of my committee, Professor Arthur Keown and Professor Ozgur Ince for their valuable insights and comments. I want to thank Professor Keown for his help in the job market.

Finally I want to thank my parents and my sister for their support and encouragement. They always stood by me in times of distress. 


\section{Table of Contents}

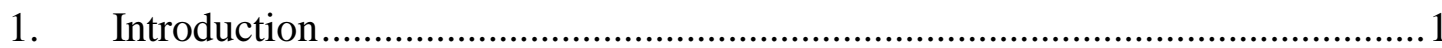

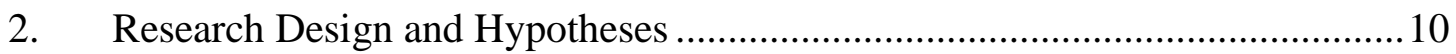

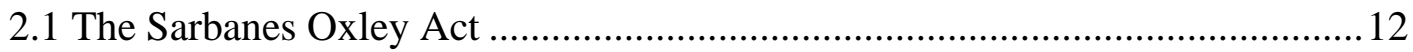

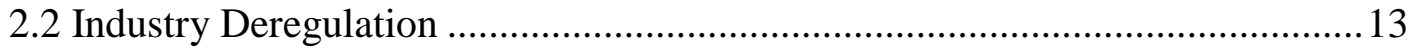

3. Empirical Analysis: Sarbanes Oxley Act..................................................... 14

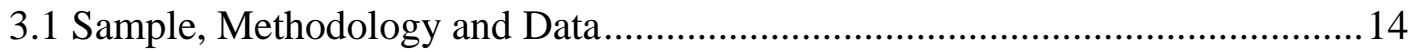

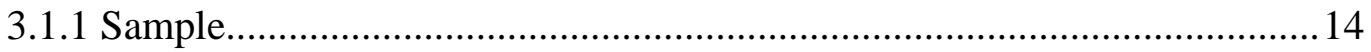

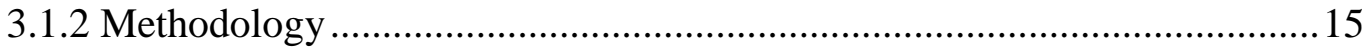

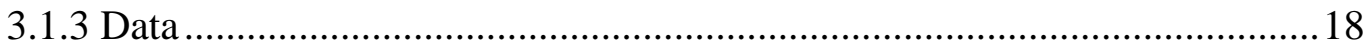

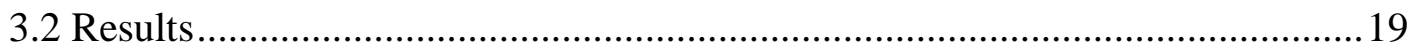

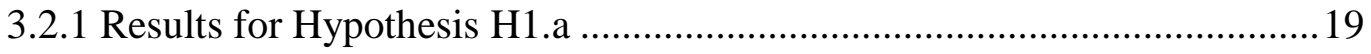

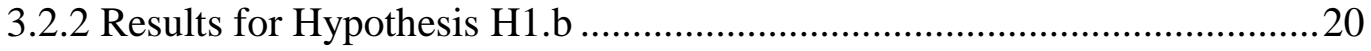

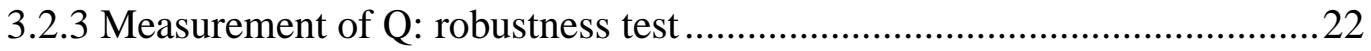

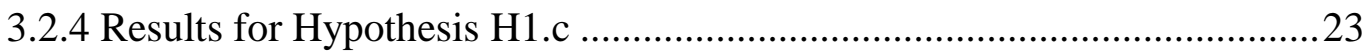

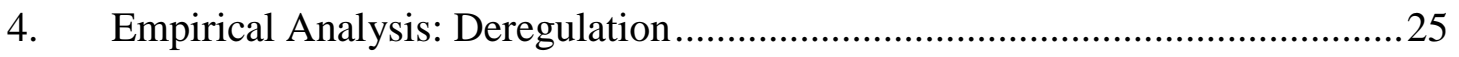

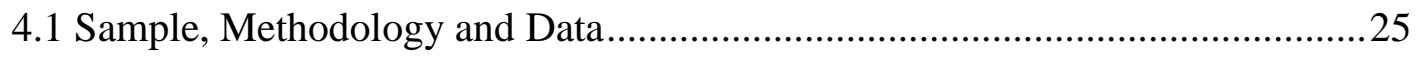

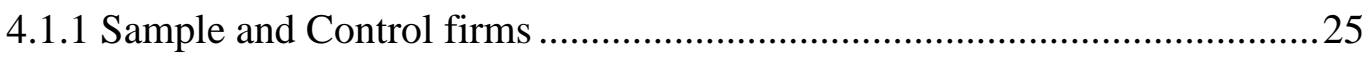




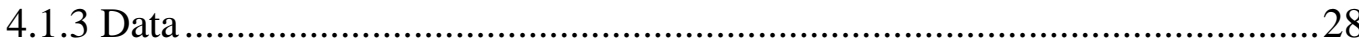

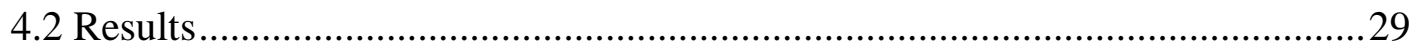

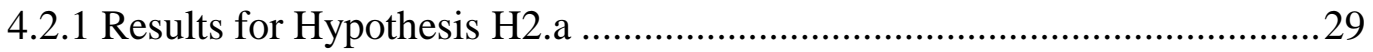

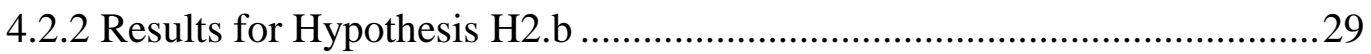

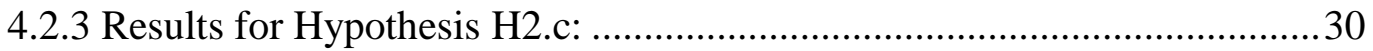

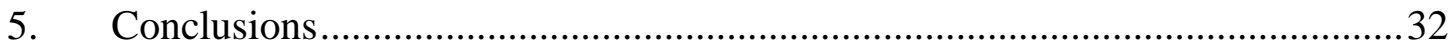

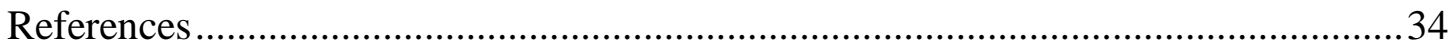

Appendix A1: Disclosure related provisions of the Sarbanes Oxley Act ......................36

Appendix A2: A summary of the relevant Deregulation Acts.....................................38 


\section{List of Tables:}

TABLE 1: DESCRIPTIVE STATISTICS OF FIRM LEVEL VARIABLES: EVENT SOX

TABLE 2 : DESCRIPTIVE STATISTICS OF INFORMATION ASYMMETRY VARIABLES: EVENT SOX

TABLE 3 : REGRESSION OF INVESTMENT ON CASH FLOW AND TOBIN'S Q: EVENT SOX 46

TABLE 4 : REGRESSION OF INVESTMENT ON CASH FLOW AND TOBIN'S Q WITH A CONTROL VARIABLE FOR MISVALUATION: EVENT SOX

TABLE 5 : REGRESSION OF INVESTMENT ON CASH FLOW AND TOBIN'S Q BASED ON ASYMMETRIC INFORMATION PROXY MARKET RESIDUAL/ TOTAL VARIANCE: EVENT SOX.

TABLE 6 : DESCRIPTIVE STATISTICS OF THE SAMPLE FIRMS: EVENT DEREGULATION .52

TABLE 7 : DESCRIPTIVE STATISTICS OF THE CONTROL FIRMS: EVENT DEREGULATION 53

TABLE 8 : DESCRIPTIVE STATISTICS OF SAMPLE MINUS CONTROL FIRMS: EVENT DEREGULATION. 54

TABLE 9 : REGRESSION OF INVESTMENT ON TOBIN'S Q AND CASH FLOW FOR SAMPLE FIRMS: EVENT DEREGULATION .55

TABLE 10 : REGRESSION OF INVESTMENT ON TOBIN'S Q AND CASH FLOW FOR CONTROL FIRMS: EVENT DEREGULATION

TABLE 11 : REGRESSION OF INVESTMENT ON CASH FLOW AND TOBIN'S Q BASED ON ASYMMETRIC INFORMATION PROXY MARKET RESIDUAL/ TOTAL VARIANCE : EVENT DEREGULATION. 


\section{Introduction}

This study re-visits the long unresolved question of whether the firm's investments are sensitive to cash flows. The paper attempts to address some of the theoretical and methodological criticisms that have cast doubts on the (often contradictory) conclusions emerging from the vast body of extant empirical work, starting with Fazzari, Hubbard and Peterson (1988).

The Q model of investments predicts that in perfect capital markets, where internal and external funds are perfect substitutes, the investment decision of a firm is solely a function of its investment opportunities, and invariant to the firm's cash flow. In imperfect markets, however, the presence of agency \& information asymmetry/costs creates a wedge between internal and external funds, making the latter more costly. Now firms with low internal funds may invest less than the first best level because external financing is more costly than internal funding. Conventional wisdom then suggests that the more financially constrained the firm either in terms of (i) capital market imperfections, or (ii) its available internal funds, the less it invests and greater is its investment-cash flow sensitivity.

All the empirical studies of the investment-cash flow sensitivity hypotheses in the literature are some variation of cross sectional regressions of investment levels against the firm's cash flow after controlling for its growth opportunity. These regressions, using panel data, are typically carried out on sub-samples of firms stratified according to some perceived degree of a priori financial constraints from capital market imperfections or availability of internal funds. The Fazzari, Hubbard and Peterson (FHP) study and some its subsequent variants use proxy measures of capital market imperfections to classify the sub-groups into different degrees of financial constraint. For example, FHP (1988) stratifies the sample using 
the firms' dividend payout ratio as a measure of market imperfection driven financial constraint. Low payout firms, it is argued, retain most of their income because they face higher cost of external financing and are therefore viewed as being more financially constrained. Hoshi, Kashyap and Scharfstein (1991) stratifies the sample according to whether or not they belong to industrial groups or keiretsus. The subsample belonging to keiretsus with a smaller wedge between internal and external financing costs are viewed as relatively unconstrained. Gilchrist and Himmelberg (1995) use bond rating as a proxy for asymmetric information to classify firms with rated bonds and commercial paper programs as relatively unconstrained. The specific hypotheses tested and supported in these studies are (i) that the coefficient of cash flows is positive, on average and (ii) importantly, the coefficient is significantly larger for the more financially constrained sub sample than for the less financially constrained sub sample. From the latter finding the studies implicitly conclude that investment-cash flow sensitivity is a useful measure of financial constraint.

However, this entrenched research design and interpretation of results are criticized by Kaplan and Zingales (1997), hereafter KZ, on theoretical grounds. Existing studies, starting with FHP (1988) implicitly conclude that investment-cash flow sensitivity is a good indicator of financial constraint based on their finding a higher sensitivity for the group perceived to be more constrained in the cross sectional regression. KZ (1997) point out that such an interpretation implicitly assumes that the investment cash-flow sensitivity increases monotonically with the degree of financial constraint and show that there is no strong theoretical reason to expect such a relation. They model a theoretical counter-example in which depending on the form of the production function chosen, the investment cash-flow sensitivity is increasing in internal funds. They provide empirical support to their argument against monotonicity by re-examining the FHP (1988) subsample with low dividend payouts, 
viewed as more financially constrained. They further subdivide the sample according to indices of the firm's financial strength and report lower investment-cash flow sensitivity for the most constrained sub-group in this classification scheme as evidence against the assumption of monotonicity. Cleary (1999) also stratify their sample according to indices of the firm's financial strength and report lower cash-flow sensitivity for the more constrained group. To the extent that the financial strength of the firm is likely to be strongly correlated with its internal funds, KZ (1997) and Cleary (1999) stratify their sample based on availability of internal funds in contrast to FHP (1988) and others who classify the sub groups according to proxy measures of capital market imperfection/information asymmetry. Thus the literature documents conflicting results depending on which classification scheme is used.

KZ (1997) also point out that the proxies used in the literature, for asymmetric information or internal funds are "only able to identify constrained firms, not constrained firm-years. This makes it impossible to disentangle the effect of financing constraints from firm-specific effect on the level of investment. For these reasons studies have focused on cross-sectional differences in investment cash-flow sensitivity across groups of firms that are likely to have a different wedge between internal and external funds", and the cross-sectional studies are subject to the criticism of the monotonicity assumption.

The second common problem in this literature is related to the measurement errors in the marginal Tobin's Q. Traditionally, the literature uses an average Q measure proxied by the firm's market to book ratio. It is argued that the biased coefficients from the measurement error in Q could explain the observed investment-cash flow sensitivity results. For example, Cummins, Hassett and Oliner (2005) ( hereafter CHO) and Erickson and Whited (2000,2002) 
(hereafter EW) take two different approaches to solve for this measurement error and report that after controlling for measurement errors, the investment-cash flow sensitivity is statistically insignificant. CHO replace the market value of equity, which could be over/under valued, by the intrinsic value of equity from analyst forecast of earnings per share to construct a market to book proxy for Q in their GMM panel regressions. Agca and Mozumdar (2008) point out that $\mathrm{CHO}$ results hold for one lead period of cash flow $C F_{i t+1}$ and not with contemporaneous cash flow $C F_{i t}$. EW use higher third, fourth and fifth order moments in the GMM regressions. Agca and Mozumder (2008) suggest that EW results may not be robust. They find that EW results do not hold up to small changes in variable construction and are reversed when the data period is increased from 4 years to 22 years. Further, if one incorporates analyst based measure of $\mathrm{Q}$ in the regressions the EW results are overturned. Thus, the issue of measurement error in $\mathrm{Q}$ has not been satisfactorily resolved in the literature.

A more recent study by Cleary, Povel and Raith (2007), hereafter CPR, reconciles the seemingly contradictory empirical findings of FHP and $\mathrm{KZ}$ who use alternative sample classification schemes to identify more and less constrained subgroups, viz., information asymmetry proxies and internal fund availability, respectively. CPR (2007) model investments as a $\mathrm{U}$ shaped function of internal funds. Their theoretical model is based on three key assumptions: (i) investments is scalable with investors deciding not only whether to invest or not but also how much to invest, (ii) the internal funds of the firms can be negative, and importantly (iii) the costs of external financing is determined endogenously. The last assumption is in sharp contrast to Kaplan and Zingales (1997) who specify an exogenous cost function. The explanation for the $U$ shaped investment-internal funds 
function based on these reasonable assumptions is quite intuitive. If there is a decrease in firm's internal funds, the firm must increase external (debt) financing in order to maintain the same level of investment which increases the probability of bankruptcy and is a cost to the investors. In order to keep the risk of bankruptcy constant the firm may reduces investment, instead of borrowing more, when there is a decrease in internal fund. This is the cost effect of a decrease of internal funds which predicts declining investment when there is a reduction in available internal funds. However, there is countervailing revenue effect. A decrease in investment from a reduction in internal funds reduces revenues, hence expected repayments to investors. The revenue effect suggests a possible increase in investment when the firm is faced with reduced internal funds. The increased investment increases the expected repayment to investors which may reduce the (now endogenously determined) cost of external funds and default risk. The overall impact on the (scalable) investment then depends on the tradeoff between the cost effect and revenue effect resulting in a $U$ shaped investment function. At high positive levels of internal funds the cost effect dominates the revenue effect, which will be small if the firm is close to its first best level of investment, leading to the intuitive prediction that a decrease in internal funds decreases investment. At low/negative levels of internal funds, the revenue effect dominates the cost effect and firms may increase its investment when internal funds decline to generate more revenues to increase expected payoffs to investors thereby reducing marginal cost of external firms and the already high default risk. Hence, a U shaped investment curve. An important implication of the $\mathrm{U}$ shaped investment function is that when the classification scheme is based on internal funds, as in KZ (1999) and Cleary (1999), then, depending on the sample composition, firms identified as financially constrained may have higher or lower investment-cash flow sensitivity. Since KZ (1999) start with the more constrained FHP 
(1988) sub-sample and further stratify it according to internal funds, their more constrained group is likely to consist of low/negative cash flow firms resulting in lower observed investment- cash flow sensitivity, contrary to conventional wisdom but consistent with the prediction of the CPR (2007) model.

An extension of their model, CPR (2007) "captures the idea that two otherwise identical firms may face differently severe problems of information asymmetry". The model now predicts that when firms have positive internal funds, positively related to investments, ---- in the right segment of the U curve ---- "greater asymmetry of information should be associated with greater sensitivity of investments to changes in internal funds". For sufficiently negative internal funds, ----- in the left segment of the $U$ curve ----- the extended model predicts that the investment-cash flow sensitivity will still be higher the higher the information asymmetry, but the correlation is now negative. The FHP (1988) study stratifies the sample based on a proxy measure of information asymmetry, and eliminates the low internal fund firms in the sample construction. Their result of investment cash-flow sensitivity increasing with financial constraints is then consistent with the prediction of the CPR (2007) model.

Overall, the literature suggests that despite 30 plus years of research on the subject of investment cash flow sensitivity, several concerns, both theoretical and empirical remain. In summary, these concerns are (i) conflicting results depending on the criteria used to stratify the sample --- information asymmetry or internal funds, (ii) the inability of either criteria to identify constrained firm-years, as opposed to just constrained firms, necessitating a crosssectional analysis of differences in sensitivity across groups to disentangle the effect of financing constraint from firm- specific effect on investment, (iii) the implicit and 
questionable assumption in the interpretation of the cross-sectional results that investmentcash flow sensitivity increases monotonically with financial constraint, (iv) measurement errors in Q, and finally, (v) the appropriateness of the measures of market imperfections/information asymmetry used by FHP (1988) and its variants to classify their sample. CPR (2007) point out in the context of the FHP (1988) study that "the problem is that it is difficult to find good proxies for capital market imperfections that vary enough across observations in the sample".

In this study we use the insights of the CPR (2007) and a new research design to mitigate some of these theoretical and empirical problems. First, we stratify the sample based on asymmetric information as a measure of the severity of financial constraint. CPR (2007) predicts unambiguously higher investment-cash flow sensitivity for the more constrained/high information asymmetry firms when the financially weakest firms are excluded from the sample. We use residual variance of the market model and bid-ask spreads as alternative measures of information asymmetry. These measure are generally accepted in the literature and improve upon the broad proxies such as dividend payout rates used in FHP (1988) and related studies. Importantly, instead of examining cross sectional differences in investment-cash flow sensitivities across more or less constrained groups as in most previous studies, we estimate the change in investment-cash flow sensitivity resulting from exogenous shocks that decrease or increase the information asymmetry, for the same set of firms, in a time-series framework. The time series framework surrounding events that change information asymmetry potentially mitigates some of the measurement problems identified in the literature, in addition to resolving the monotonicity issue. By examining differences over time for the same firms the time series framework is expected to more effectively separate the impact of firm specific factors on investment from the impact of financial constraints than the 
cross sectional groupings used in the literature. Further, we argue that some of the biases in the coefficients arising from measurement error on the $\mathrm{Q}$ variable would cancel out in this research design. To the extent that the event itself can induce changes in the firm-specific factors and in $\mathrm{Q}$, the correction from examining differences over time is partial.

We study two events that exogenously impact a firm's information asymmetry. The first exogenous shock we examine is the implementation of the Sarbanes Oxley Act of 2002 (SOX). We hypothesize that the implementation of SOX, with its requirement of increased disclosures, decreases the information asymmetry between the firm and the market. Accordingly, following CPR (2007) we expect an unambiguous decrease (increase) in the firms' investment-cash flow sensitivity, pre- to post SOX, for firms with positive (negative) cash flows with larger changes for subsamples of firms with larger decreases in information asymmetry. Our results are consistent with these hypotheses.

The second exogenous shock we study is the deregulation of industries which brings about significant changes in the operating and information structure of the firms in the industries. We hypothesize with supporting arguments that deregulation increases the information asymmetry between the firm and the market. Accordingly, we expect an unambiguous increase (decrease) in the firm's investment-cash flow sensitivity, pre- to post deregulation for positive (negative) cash flow firms, with larger changes for subsamples of firms with larger increases in information asymmetry. We report weaker support for these hypotheses.

To the best of our knowledge, this is the only paper that examines investment cashflow sensitivity in a time-series framework surrounding events that exogenously change the firm's information asymmetry, the primary determinant of its investment-cash flow 
sensitivity. The primary contribution of the paper is the new research design that effectively mitigates several of the problems outstanding in the literature, as discussed above. Additionally, the paper provides insights into how the SOX regulation and industry deregulation changes information asymmetry between the firm and the investors. Such changes have obvious and important implication on the decisions of corporations and investors.

The rest of the paper is organized as follows: In Section 2, we discuss the research design and primary hypotheses of the paper. Sections 3 and 4 present the empirical analyses and results for the SOX and deregulation events, respectively. Section 5 concludes the paper. 


\section{Research Design and Hypotheses}

Previous empirical tests of the investment-cash flow sensitivity have typically used panel data to estimate the following cross sectional regression for sub samples of firms stratified by the perceived degree of a priori financial constraints, either based on proxy measures of capital market imperfection (FHP (1988) and others) or availability of internal funds (KZ (1999) and others): ${ }^{1}$

$$
\frac{I_{i t}}{K_{i t-1}}=\alpha+\beta_{1} q+\beta_{2} \frac{C F_{i t}}{K_{i t-1}}+\varepsilon_{i t}
$$

Where,

$$
\begin{aligned}
& \text { I = Investments } \\
& \text { K= Capital stock } \\
& \mathrm{Q}=\text { Tobin's Q, a measure of growth opportunities } \\
& \mathrm{CF}=\text { Cash flow. }
\end{aligned}
$$

The investment-cash flow hypothesis is then considered supported if the coefficient $\mathrm{c}$ is significantly positive and higher in the subsamples that are perceived to be a priori more financially constrained.

In Section I we pointed out several problems with such an empirical design

\footnotetext{
${ }^{1} \mathrm{We}$ also estimated the regressions with size as an additional control. The results are similar.
} 
discussed in the literature. Conflicting results are reported depending on the classification schemes used to identify the more or less constrained groups ---- capital market imperfection or internal funds. Neither classification scheme is able to identify constrained firm-years making it impossible to disentangle the effect of financing constraints from firm-specific effect on the level of investment. For this reasons studies have focused on cross-sectional differences in investment cash-flow sensitivity across groups of firms in order to average out the firm-specific effects. However, the conclusions of the cross-sectional studies are based on the questionable assumption that the investment cash-flow sensitivity increases monotonically with the degree of financial constraint as pointed out by KZ (1997). Finally, there is the ever present concern about biased coefficients resulting from measurement errors in $\mathrm{Q}$.

In this paper we attempt to correct for some of these problems. First, we stratify the sample based on direct measures of asymmetric information as a measure of the severity of financial constraint. The CPR (2007) model predicts unambiguously higher investment-cash flow sensitivity for the more constrained, higher information asymmetry firms. Second, we test for time series changes in the investment cash flow sensitivity resulting from an exogenous change in information asymmetry which constitutes the primary wedge between internal and external funds. Accordingly, we estimate Equation 1 for the same set of firms in the pre- and post periods around the exogenous change in information asymmetry. This research design mitigates some of the problems of (i) separating the impact of firm specific factors on investment from the impact of financial constraints, and (ii) biased coefficients from measurement errors in Q.

We examine two events that exogenously impact a firm's information asymmetry: (i) 
the implementation of SOX which is expected to reduce information asymmetry and (ii) the event of deregulation which is expected to increase information asymmetry. Our primary hypotheses for the two information asymmetry changing exogenous events are as follows:

\subsection{The Sarbanes Oxley Act}

Sarbanes Oxley Act came into force in 2002 and introduced significant changes in the quality and extent of the firms' disclosures. The Act is arranged into eleven titles of which Sections 302, 401, 404, 409, and 802 pertain specifically to improved and increased disclosure. For example, Section 409 requires disclosures of information on material changes in the financial conditions or operations of the firm on an urgent basis. Brief descriptions of these sections are provided in Appendix A1. The Sarbanes Oxley Act with its increased disclosure requirement is expected to reduce information asymmetry leading to the following hypotheses:

H1.a: Information asymmetry decreases following SOX, on average.

H1b: The investment cash flow sensitivity decreases following SOX for positive cash flow firms, on average:

Coefficient $\beta_{2}$ (post SOX) $<$ Coefficient $\beta_{2}$ (pre SOX)

and increases for negative cash flow firms, on average:

Coefficient $\beta_{2}$ (post SOX) > Coefficient $\beta_{2}$ (pre SOX).

H1.c : A greater decrease in information asymmetry following SOX is associated with a greater change in investment-cash flow sensitivity, pre to post SOX. 


\subsection{Industry Deregulation}

We examined the deregulation of three industries in this study: (i) Transportation (Fama French industry code 40), (ii) Telecommunication (Fama French industry code 32) and (iii) Petroleum and Natural Gas (Fama French industry code 31). Each deregulation event typically involves elimination of entry/exit restrictions and/or and price decontrol. For example, in the airlines industry the deregulation provisions reduce entry restrictions and eliminate fare control. Appendix A2 describes in more detail the provisions of the deregulation Acts and their expected impact on the firms operating environment and information asymmetry. In general, free entry and exit accompanied by the elimination of price controls is expected to lead to a more competition and uncertain business environment which in turn is expected to increase the information asymmetry between the managers and investors leading to the following hypotheses:

H2.a: Information asymmetry increases following industry deregulation, on average.

H2.b: The investment cash flow sensitivity increases following deregulation for positive cash flow firms, on average:

Coefficient $\beta_{2}$ (post deregulation) $>$ Coefficient $\beta_{2}$ (pre deregulation) and decreases for negative cash flow firms, on average:

Coefficient $\beta_{2}$ (post deregulation) $<$ Coefficient $\beta_{2}$ (pre deregulation).

H2.c : A greater increase in information asymmetry following deregulation is associated with a greater change in investment-cash flow sensitivity. 


\section{Empirical Analysis: Sarbanes Oxley Act}

This section presents the empirical analysis of the tests of hypotheses H1.a, H1.b and H1.c pertaining to SOX as the information asymmetry changing event.

\subsection{Sample, Methodology and Data}

\subsubsection{Sample}

Our base sample of firms for the SOX event consists of all US firms listed on NYSE, AMEX or NASDAQ that are present in CRSP and COMPUSTAT for each of the years preand post SOX. The event year is 2002. The pre-event years for SOX are 1999, 2000, 2001. The post event years are 2003, 2004 and 2005. We exclude financial companies (SIC 6000 to 6999) and utility companies (SIC 4900 to 4999) to exclude possible effects of regulation on the analysis. We also exclude firms with asset less than 75 million as SOX does not apply to these firms. Our final sample in the pre and post Sox are the same set of firms that entered the sample in 2002.

To test Hypothesis H1.b we stratify the primary sample into sub-samples of positive and negative cash flow firms. We calculate the mean cash flow of each firm over three years for both the pre and the post periods. If the mean cash flow of a firm is positive for both periods, the firm is classified as a positive cash flow firm. If the mean cash flow of a firm is negative for both periods the firm is a negative cash flow firm.

A problem encountered in most studies in the SOX literature is the difficulty in identifying a control group of comparable firms that are not affected by SOX since the Act ct is applicable to most US listed firms. The absence of a control group is particularly 
problematic in studies related to the market reaction/returns from SOX as it becomes difficult to isolate the impact of SOX from the effect of the prevailing market conditions surrounding the implementation of SOX. The problem is less severe in our study since we are examining changes pre- to post- SOX for largely the entire population of firms. For the deregulation event, we have a control firm for every sample firm and report results generally consistent with our hypotheses.

\subsubsection{Methodology}

Test of Hypothesis H1.a: To test Hypotheses H1.a that information asymmetry decreases following the implementation of SOX we test for the sign and significance of the change in measures of information asymmetry pre- to post SOX. We estimate two alternative measures widely used in the literature:

(i) The standard deviation of market model residuals estimated by regressing daily stock returns against value-weighted market returns over a 250 day estimation horizon. It is possible that the standard deviation of the market model residual may be increasing (decreasing) because the total variance may be increasing (decreasing) due to some economy wide factor. This could lead to a false inference that the asymmetric information for a particular firm is changing by observing just the change in the standard deviation of market model residuals. To guard against such a false inference we define a related proxy which is the ratio of the standard deviation of market model residuals to the total variance. This measure will increase (decrease) only if the standard deviation of market model residuals increase (decrease) with respect to the total variance and is a better proxy for asymmetric information. 
(ii) The second measure of information asymmetry is the bid ask spread. We estimate bid-ask spreads from daily high and low prices based on the methodology of Corwin and Schultz (2010). Their methodology is idea is based on two widely accepted ideas. First, the daily high (low) prices are almost always buy (sell) orders and that the high-low price ratio reflects both the stock's variance and its bid-ask spread. Second, the variance component of the high-low ratio is proportional to the return interval, while the bid-ask spread component is not. Based on these two ideas, Corwin and Schultz (2010) derive a spread estimator as a function of high-low ratios over one-day and two-day intervals.

Test of Hypothesis H1.b: To test Hypothesis H1.b we estimate two sets of regressions for the positive and negative cash flow subsamples. The first regression estimates the basic specification separately for the pre- and post- Sox period:

$$
\frac{I_{i t}}{K_{i t-1}}=\alpha+\beta_{1} q+\beta_{2} \frac{C F_{i t}}{K_{i t-1}}+\varepsilon_{i t}
$$

A significantly lower (higher) $\beta_{2}$ in the post-SOX period for the positive (negative) cash flow subsamples, respectively, is consistent with the hypothesis.

In the second regression we estimate pooled regression of the panel data including an interaction terms between the SOX dummy variable (=1.0 for the post SOX period) and the all the independent variables in an "all unrestricted" specification:

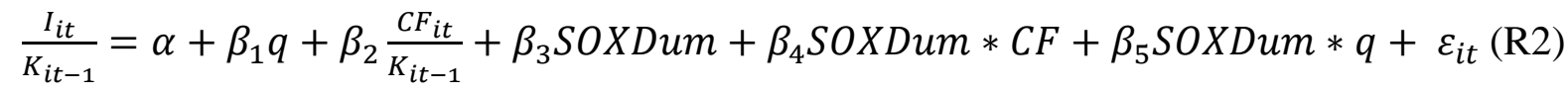


One may argue that pooling the data may deflate the standard error of the coefficients because of time series dependence of observations for each firm, overstating their significance. The standard panel data approach of including firm fixed effect to control for time dependence across firm specific observations may not be feasible since we have only three data points for the three years of data for each firm. Instead to control for dependence among these three data points we take the time series mean of the variables for every firm and then estimate a regression with each firm having one data point. A significantly negative (positive) $\beta_{4}$ for the positive (negative) cash flow subsamples, respectively, is consistent with the hypothesis H1.b. We also carry out a Chow-Fisher test for a structural shift in the regression attributable to just the change in the cash flows, pre- to post SOX. To do so we reestimate the regression with all variables unrestricted except the cash flow variable. The Chow Fisher statistic is then calculated using the residual sum of squares from the "all unrestricted speciation" (R2) and the "all but cash flow unrestricted" regression described above.

Test of Hypothesis H1.c: To test Hypothesis H1.c that a greater decline in information asymmetry pre- to post SOX is associated a greater changes in investment-cash flow sensitivity we estimate tercile regressions of specification R2 and compare coefficient $\beta_{4}$ across the terciles based on changes in the alternative measures of information asymmetry. A finding that the changes in investment-cash flow sensitivity are larger in terciles with the greater reduction in information asymmetry is consistent with Hypothesis H1.c. 


\subsubsection{Data}

Variable Measurement: COMPUSTAT is the primary data source for measuring the input variables to the basic regression specification:

$$
\frac{I_{i t}}{K_{i t-1}}=\alpha+\beta_{1} q+\beta_{2} \frac{C F_{i t}}{K_{i t-1}}+\varepsilon_{i t}
$$

The variables are defined and measured as in Kaplan and Zingales (1997) ${ }^{2}$

Investment I is the annual capital expenditure (data item 128)

Capital stock $K$ is Property Plant and Equipment, PP\&E (data item 8)

Tobin's $q$ is the market value of asset divided by the book value of asset. Market value of asset is the sum of the book value of asset (data item 6) + market value of equity (data $25 x$ data 199) - the sum of the book value of common equity (data item 60) and deferred taxes (data item 74). Cash flow $C F$ is the sum of earnings before extraordinary items (data item 18), and depreciation (data, item 14).

Descriptive Statistics: In Panels A, B and C of Table 1 we report descriptive statistics of the regression variable, pre- and post-SOX, for the total sample and for the positive and negative cash flow subsamples. The pre period is the three year period $(-3,-2$, and-1) before the event year $(0)$ in 2002 . The post period is three years after the event year $(1,2$, and 3$)$. The sample

\footnotetext{
${ }^{2}$ Following FHP, we also used an alternate data definition by scaling the variables by
} total assets. We replicated all our tables using this alternate data definition. The results were qualitatively similar. 
mean and median values in columns 1 through 4 are for the three year averages of the variables in the pre- and post-years. Columns 5 and 6 report the differences in the mean and median values, post-pre, and the statistical significance of the differences. For the median differences we report the $\mathrm{p}$ values of the non-parametric Wilcoxon Sign Rank test in column 6. Since the difference in mean is likely to be non-normal violating the assumption of the standard t test, we bootstrap the sample and report $\mathrm{p}$ values of the bootstrapped mean in column 5 .

From panels A, B and C, the mean (median) investment decreases significantly pre to post SOX for all three samples. In each case the decrease in investment is consistent with the reported decrease in growth opportunity as measured in Tobin's Q. The decline in Q and investments likely reflects the weakening economy and concerns about the efficacy of corporate governance which led to the implementation of SOX. The change in cash flow is significantly positive for the total sample largely from the cash flow increase/recovery in the negative cash flow subsample. We report no significant change in the variable for the positive cash flow subsample, pre- to post SOX. Finally, the median size of the positive cash flow subsample is about three times larger than that of the negative cash flow subsample.

(Insert Table 1 about here)

\subsection{Results}

In this section we report the results of our tests of hypotheses H1.a, H1.b and H1.c

\subsubsection{Results for Hypothesis H1.a}

In Panels $\mathrm{A}, \mathrm{B}$ and $\mathrm{C}$ of Table 2 we report alternative measures of information asymmetry described in Section 3.1.2, pre and post SOX and their differences, for the total 
sample subsample of positive cash flow firms, and subsample of negative cash flow firms, respectively. The mean and median values of information asymmetry measured as standard deviation of the market model residuals decreases significantly pre-post SOX for all three samples. The mean and median ratio of the standard deviation of market model residual to total variance also decreases significantly for the total sample (Panel A) and for the positive cash flow subsample (Panel B). However the change in the ratio is insignificant for the negative cash flow subsample (Panel C). When information asymmetry is measured as the bid-ask spread we report a large and significant decline in the spread for all three samples in Panels A, B and C. ${ }^{3}$

Overall, the empirical evidence is consistent with hypothesis H1.a that the increased firm disclosure required by SOX has reduced the information asymmetry between the firm and the investors.

(Insert Table 2 about here)

\subsubsection{Results for Hypothesis H1.b}

Hypothesis H1.b predicts that the decrease in information asymmetry following the

${ }^{3}$ One may argue that the drop in the bid ask spread is a result of the decimalization of the bid ask spread which began in late 2000 and ended in January $29^{\text {th }}, 2001$. We estimated the bid ask spread for the year 2001 and 2003. Decimalization of bid ask spread had already been in effect in 2001 . Hence if there is a drop in the bid ask spread from 2001 to 2003, that drop can be attributed to the factors other than decimalization, factors like SOX. We found that there was a significant drop in the bid ask spread from 2001 to 2003, similar to the results in table 2. There was a similar drop in the bid ask spread from the last three quarters of 2001 to last three quarters of 2003. So it can be inferred that our results of a decrease in the bid ask spread from pre to post SOX period holds even after controlling for decimalization. 
implementation of SOX (from H1.a) is associated with decline in investment-cash flow sensitivity for positive cash flow firms and an increase in the sensitivity for negative cash flow firms. Panels $A$ and $B$ of Table 3 report the regression estimates of the model specifications described in Section 3.1.2 for the positive and negative cash flow subsamples, respectively. We estimate the first specification R1, below, separately in the pre- and post SOX period and test for the significance of the change in $\beta_{2}$ :

$$
\frac{I_{i t}}{K_{i t-1}}=\alpha+\beta_{1} q+\beta_{2} \frac{C F_{i t}}{K_{i t-1}}+\varepsilon_{i t}
$$

From columns 1 and 2 of Panel A the coefficient $\beta_{2}$ declines from 0.13 to 0.09 . The decline is statistically significant as evidenced by the significantly negative coefficient $\beta_{4}$ of the SOX Dummy-Cash Flow interaction term in the estimate of "all unrestricted" specification R2 below:

$\frac{I_{i t}}{K_{i t-1}}=\alpha+\beta_{1} q+\beta_{2} \frac{C F_{i t}}{K_{i t-1}}+\beta_{3}$ SOXDum $+\beta_{4}$ SOXDum $* C F+\beta_{5}$ SOXDum $* q+\varepsilon_{i t}$

The Chow Fisher statistic is significantly positive consistent suggesting a structural shift from the cash flow variable alone.

Panel $\mathrm{B}$ reports an increase in $\beta_{2}$ from -0.04 to -0.02 and a significantly positive coefficient $\beta_{4}$ of the SOX Dummy-Cash Flow interaction term in the pooled regression. 
Thus the results from these regression estimates are consistent with Hypothesis H1.b of a declining investment-cash flow sensitivity post SOX for positive cash flow firms, on average, and increasing investment-cash flow sensitivity for negative cash flow firms, on average.

(Insert Table 3 about here)

\subsubsection{Measurement of Q: robustness test}

An ongoing criticism of the cross-sectional regressions used in all the studies on investment-cash flow sensitivity is that measurement errors in $\mathrm{Q}$ could lead to biased coefficients. We expect some of these concerns to be mitigated in our time series approach surrounding exogenous shocks to information asymmetry. Our hypotheses are based on the difference in investment cash flow sensitivity coefficient, pre- to post event, cancelling out some of the biases in the coefficient estimates from measurement errors in Q. However, this correction is by no means complete. In this section we test for the robustness of our results for Hypothesis H1.b by more directly addressing the measurement error in Q problem. The test is carried out on the positive cash flow subsample.

A problem with the traditional Tobin's Q measure as a firm's market to book ratio is that it may capture both growth opportunity and the possible overvaluation/undervaluation of a firm by the market. We address the misvaluation problem by including a control variable in the regression specification that measures such misvaluation. The misvaluation measure is based on Dong, Hirshleifer, Teoh (2007) who estimate the intrinsic value of a firm (V) from the residual income model. Misvaluation is then defined as $\mathrm{E} / \mathrm{V}$ where $\mathrm{E}$ is the market value 
of the firm. Table 4 reports the estimates of specifications R1, and R2 with the misvaluation variable as an added control variable. From columns 1 and 2 the investment cash flow sensitivity decreases significantly from 0.13 to 0.09 . From column 3 the coefficient $\beta_{4}$ of the cash flow variable interacted with the SOX dummy is a significantly negative in the "all unrestricted" specification R2. The Chow Fisher statistic is significantly positive consistent with a structural shift from the cash flow variable alone. Thus, Hypothesis H1.b is supported even after correcting for the misvaluation component in the measure of Q.

\section{(Table 4 about here)}

\subsubsection{Results for Hypothesis H1.c}

Tests of Hypothesis H1.b report that the investment-cash flow sensitivity decreases pre- to post SOX, on average, for positive cash flow firms consistent with the SOX induced decrease in information asymmetry. In Hypothesis H1.c we test whether larger decreases in information asymmetry are associated with larger decreases in investment cash-flow sensitivity. To do so we divide our sample of firms into terciles based on changes in the alternative the measures of asymmetric information, pre- to post, and estimate the regressions for each tercile. The first tercile (1) consists of firms with the largest declines in information asymmetry and the third quintile (3) has firms with the smallest declines. The test is carried out on the larger positive cash flow subsample. Hypothesis H1.c is supported if the decrease in investment cash flow sensitivity decreases from tercile 1 to tercile 3.

Table 5 reports the results of the tercile regressions with the ratio of market model residuals to total variance as the measure of information asymmetry. Panel A of Table 5 reports the declines in information asymmetry, pre to post, from tercile 1 to tercile 3 and Panel B presents the tercile regression estimates of the specification R1 and the "all 
unrestricted" specification R2. The information asymmetry declines more in tercile 1 than in tercile 2 than in tercile 3 by design. However, the corresponding reduction in investment-cash flow sensitivity does not decrease monotonically. For the first tercile with the largest reduction in information asymmetry the investment-cash flow sensitivity coefficient decreases from 0.10 to 0.06 with a significant negative coefficient of -0.04 for the cash flowSOX dummy interaction term in the all unrestricted specification R2. For the third tercile with the smallest decline in information asymmetry --- in fact an increase on average --- the investment cash flow sensitivity is lowest as expected and statistically insignificant. However, for tercile 2 where the information asymmetry decline is smaller than in tercile 1 we report a higher investment-cash flow sensitivity, a finding not consistent with a monotonic association between asymmetry declines and sensitivity declines. Overall, there is weak support for Hypotheses H1.c.

(Tables 5 about here) 


\section{Empirical Analysis: Deregulation}

This section presents the empirical analysis of the tests of hypotheses H2.a, H2.b and $\mathrm{H} 2$.c pertaining to deregulation as the information asymmetry changing event. In this analysis we test the hypotheses pertaining to the positive cash flow subsample since the sample of negative cash flow firms at 20 is small.

\subsection{Sample, Methodology and Data}

\subsubsection{Sample and Control firms}

Our sample includes firms from deregulated industries within three broad industry classifications: (i) transportation (Fama French industry code 40), (ii) telecommunication (Fama French industry code 32) and (iii) Petroleum and Natural Gas (Fama French industry code 30$)$. We identify the first major deregulation event for the industry as the event year (0). The pre- deregulation period is the defined as years $-3,-2$ and -1 and post deregulation period as years $+1,+2$, and +3 . Within transportation, 1976 was the event year for the railroad industry and the airlines industries with the introduction of the Railroad Revitalization and Regulatory Reforms Act of 1976 and the lifting of entry restrictions and elimination of fare controls for airlines. Within telecommunication, the event year for the cable television industry was 1979 with the elimination of price controls price controls on pay channels. For the petroleum industry, the Administrative Decontrol Plan of crude oil price in 1979 was the first major deregulation event and hence 1979 is the event year. For the natural gas industry, we consider the 1978 Natural Gas Policy as the first act of deregulation and our event year is 1978.

In order to control for changes in informational asymmetry and cash flow sensitivity 
that may have occurred for all firms during this period, we create a matched control sample of non-deregulated firms for each of our sample firm. The matching is done on Tobin's Q, cash flow and size, the three variables that affect investments. We form deciles of the sample firms based on the values of these three variables as of the year prior to our event year. The largest size and largest cash flow deciles are further subdivided into two sub deciles to obtain a better match. Thus the total sample of all firms are grouped into 1210 portfolios based on the size (11 portfolios), cash flow (11 portfolios) and Tobin's Q (10 portfolios) groups. Each firm in the deregulated industry is assigned to one of these 1210 portfolios based on the cutoffs of Tobin's Q, cash flow and size as of the year prior to the deregulation event. Similarly, all the potential non-deregulated control firms are assigned to one of those 1210 portfolios for every year. For every sample firm there are one or more potential control firms. We select the control firm that has the lowest standardized distance from the sample firm based on Tobin's Q, cash flow and size. Our final sample consists of 179 deregulated sample firms of which 159 firms have positive cash flows and 20 have negative cash flows. Our analysis in this section is carried out on 159 deregulated and matched non-deregulated control firms.

\subsubsection{Methodology}

We essentially follow the same basic methodology to test hypotheses H2.a, H2.b and H2.c for the deregulation event as we did to test hypotheses H1.a, H1.b and H1.c for the SOX event.

To test hypothesis H1.b that information asymmetry increases following deregulation, we examine the changes in the mean and median values of alternative information asymmetry measures, pre- to post deregulation, for the sample and control firms. Finding that the 
differences in the information asymmetry measures between the sample and control firms are significantly positive would be consistent with the hypothesis.

To test hypothesis $\mathrm{H} 2 . \mathrm{b}$ that investment-cash increases significantly post deregulation, consistent with increasing information asymmetry, for positive cash flow firms we estimate the regression specification R1 and R2 described earlier. In specification R1 we separately estimate the regressions for the pre- and post periods for the sample and control firms and test for the significance of the change in the investment-cash flow sensitivity coefficient $\beta_{2}$ of the cash flow variable. A significant increase in $\beta_{2}$ for the sample firms relative to the control firms would be consistent with the hypothesis. The "all unrestricted" specification R2 is estimated as a pooled regression for samples with all variables flow variable interacted with the deregulation dummy variable which takes on a value of 1 for the posted deregulation period and zero for the pre-period. Coefficient $\beta_{4}$ of the interaction variable measures the change in investment cash flow pre- to post deregulation. Similar regression are estimated for the control sample with a dummy variable $=1$ for the post period. A significantly more positive $\beta_{4}$ for the sample firms relative to the control firms is consistent with Hypothesis H2.b.

To test Hypothesis H2.C that a greater increase in investment-cash flow sensitivity is associated with subsamples of firms with greater increases in information asymmetry we stratify the sample firms into terciles ranked by changes in information asymmetry and estimate specification $\mathrm{R} 2$ for each tercile. The hypothesis is supported if we find a higher $\beta_{4}$ for tercile (1) with the greatest increase in information asymmetry, pre- to post deregulation. 


\subsubsection{Data}

All the variables are measured as in the section 3.1.3 for the SOX event.

Descriptive Statistics: Tables 6, 7 and 8 report the descriptive statistics of the regression variables for sample firms, control firms and the differences between sample and control, respectively. The mean and median measures are for the three year average values of the variables in the pre- and post deregulation periods. Table 6 shows that for the sample firms, investments as a percentage of PP\&E increased significantly from a mean value of $31 \%$ to $39 \%$ consistent with a significant increase in Q from 1.12 to 1.42 , pre to post deregulation. Both the growth opportunities and investments appear to increase for the surviving firms, post-deregulation. The median size of the firms increases significantly but there is no significant change in cash flows as a percentage of PP\&E. Table 7 presents the corresponding results for the control firms. For the control firms there is no significant change in investments, Q, cash flow or firm size. In Table 8 we report the differences in investment, Tobin's Q, cash flow, and size between the sample and control firms in the pre- and post deregulation period. Consistent with using Tobin's Q, cash flow and size as the matching criteria to identify the control sample we report insignificant changes in these variable in the pre- period. Post deregulation, we find that the control adjusted investments, Tobin's Q and size are significantly higher for the deregulated firms. There is no significant difference in cash flows between the sample and control firms in the post period. These results are confirmed in the last two columns of Table 8 which report that the difference of the differences is positive and significant for investment, Tobin's Q and (median) size only.

(Insert Tables 6, 7 and 8 about here) 


\subsection{Results}

In this section we report the results of our tests of hypotheses H2.a, H2.b and H2.c

\subsubsection{Results for Hypothesis H2.a}

We report alternative measures of information asymmetry, described in Section 3.1.2, pre- and post deregulation, for the sample and control firms, and their differences in the descriptive statistics Tables 6, 7 and 8. From Table 6, the mean and median market model residual measure increases significantly, pre- to post deregulation, for the sample firms as does the market model residuals scaled by total variance. The sample mean bid-ask spread increases significantly but the median change is insignificant. Table 7 reports no significant increase in the men and median value of any of the asymmetry measures for the control firms. Table 8 reports the differences in the asymmetry measures between the sample and control in the pre- period (columns 1 and 2) and in the post period (columns 3 and 4) and the difference of the differences (columns 5 and 6). From columns 5 and 6, the control adjusted change is significantly positive for the market model residuals and the bid-ask spread asymmetry measures, as hypothesized. The control adjusted change is only marginally significant for the market residual to total variance ratio measure.

Overall, the results are consistent with Hypothesis H2.a that deregulation is associated with an increase in information asymmetry.

\subsubsection{Results for Hypothesis H2.b}

Tables 9 and 10 report the regression estimates for the tests of Hypothesis H2.b that investment cash flow sensitivity increases post deregulation from the deregulation-induced 
increase in information asymmetry for positive cash flow firms. The regression specifications are as described in Section 3.1.2. Table 9 presents the regression results for the sample firms and documents an increase in investment-cash flow coefficient $\beta_{2}$ pre- to post deregulation from 0.14 to 0.34 . However in column three, the coefficient $\beta_{4}$ of the interaction term in the "all unrestricted" specification R2 is positive 0.21 but only marginally significant with a tstatistic of 1.81 as is the Chow Fisher test statistic. A reason for just a marginal significance of the coefficient is the high multicollinearity between the SOX Dummy variable and the interaction variables with a variance inflation factor (VIF) of 15.5. To correct for the multicollinearity problem we drop the Dummy-Q interaction term and re-estimate the regression with just the Dummy-Cash Flow interaction term. Column 4 of the (pooled 2) table now reports a significantly positive albeit lower sensitivity coefficient of 0.18 with a tstatistic of 3.31. From Table 10 which reports the results for the control firms for the same set of regressions, we note that the change in $\beta_{2}$ from the separate regressions in the pre- and post period is statistically insignificant with statistically insignificant coefficients for the sensitivity coefficient $\beta_{4}$ for the "all unrestricted" model (column 3 ) and only the cash flow variable unrestricted specification (column 4). The Chow Fisher test statistic is also statistically insignificant. Overall, these results support the hypothesis that the investmentcash flow sensitivity increases post deregulation for the deregulated sample relative to the non-deregulated control firms.

(Insert Tables 9 and 10 about here)

\subsubsection{Results for Hypothesis H2.c:}

Tests of Hypothesis H2.b report that the investment-cash flow sensitivity increases pre- to post deregulation on average, consistent with the deregulation induced increase in 
information asymmetry. In Hypothesis H2.c we test whether a larger increase in information asymmetry is associated with larger increase in investment cash-flow sensitivity. We stratify the sample firms into terciles based on changes in the alternative the measures of asymmetric information, pre- to post, and estimate the regressions for each tercile. The first tercile (1) consists of firms with the smallest increase in measures of information asymmetry and the third tercile (3) consists of firms with the largest increase. Hypothesis H2.c is supported if the investment cash flow sensitivity is positive and increasing from tercile 1 to tercile 3.

Table 11 reports the results of the tercile regressions with the ratio of market model residuals to total variance as the measure of information asymmetry, as used in testing H1.c for the SOX event. Panel A of Table 11 reports increases in the increase information asymmetry, pre to post, from tercile 1 to tercile 3, as expected by design. Panel B presents the tercile regression estimates of the specification $\mathrm{R} 1$ separately for the pre- and and post periods, and the pooled dummy regression with only the cash flow variable interacted with the deregulation dummy to correct for the multicolliniearity problem identified in the test of H2.b .We report comparable, positive but statistically insignificant cash flow sensitivity coefficient for all three terciles possibly because of the small number of observations in each tercile. Our results are not consistent with Hypothesis H2.c.

(Tables 11 about here) 


\section{Conclusions}

The extant investment-cash flow literature is open to several criticisms, both conceptual and empirical. Almost all the studies in the literature are some variation of a cross sectional regression across subgroups of firms classified according to some a priori measure of perceived financial constraint. Conflicting results are then reported depending on whether the classification is based on proxy measures of capital market imperfection or availability of internal funds. Conceptually, the conclusion of these studies that a higher observed investment -cash flow sensitivity reflects greater financial constraint requires the assumption that the sensitivity increase monotonically with financial constraints, an assumption for which there is no theoretical basis. Finally, the issue of biased coefficients from measurement error in Q has not been satisfactorily resolved.

In this study we mitigate some of these problems reported in the literature by using the insights from the Cleary, Povel and Raith (2007) in a new research design. We stratify our sample using direct measures of information asymmetry, not cross-sectionally but in a time series framework surrounding events that are expected to significantly change the firms' information asymmetry. We test for the significances of the changes in the cash flow sensitivity for the same set of firms surrounding an exogenous shock to the firms' information asymmetry. The CPR (2007) model predicts an unambiguous increase (decrease) in investment-cash flow sensitivity when information asymmetry of the firm increases (decreases) for positive cash flows. Further, by examining the differences in the sensitivity coefficients we expect some of the biases in the sensitivity coefficient from measurement errors in Q to cancel out.

The two events we study are (i) the implementation of SOX which is expected to 
decrease information asymmetry from improved and increased disclosure and (ii) the deregulation of industries which is expected to increase information asymmetry largely from the lifting of price controls and entry barriers.

We report that information asymmetry indeed decreases following SOX and that there is a commensurate decrease in the investment-cash flow sensitivity pre- to post SOX, with generally greater declines in the sensitivity for subsamples with the greater declines in information asymmetry. For the deregulation event also, we report support for the hypotheses that information asymmetry increases following deregulation with a commensurate increase in investment cash flow sensitivity, pre to post deregulation. However, the hypothesis of a greater increase in the sensitivity for the subsamples with the greater increase in information asymmetry is not supported by the data.

Overall, however, the study supports the investment-cash flow sensitivity hypothesis using a research design that corrects for some of the problems identified in the existing literature on the hypothesis. 


\section{References}

Agca, Senay., Mozumder, Abon., 2008. Investment cash flow sensitivity: myth or reality?

Working paper.

Cleary, S., 1999. The relationship between firm investment and financial status. Journal of Finance 54, 673-691.

Cleary, S., Povel, P., Raith, M., 2007. The U-shaped investment curve: theory and evidence. Journal of Financial and Quantitative Analysis 42, 1-39

Cummins, J., Hasset, K., Oliner, S., 2006.Investment behavior, observable expectations and internal funds. American Economic Review 96, 796-810.

Dong, Ming., Hirshleifer, David., Teoh, Siew., 2007. Stock market misvaluation and corporate investment. Working paper.

Hoshi, Takeo., Kashyap, A., Scharfstein, David., 1991. Corporate structure, liquidity, and investment: evidence from Japanese Industrial Groups. Quarterly Journal of Economics, 106(1), 33-60.

http://www.soxlaw.com/s302.htm.

Erikson, T., Whited, T., 2000. Measurement error and the relationship between investment and Q. Journal of Political Economy 108, 1027-1057.

Fazzari, S., Hubbard, R., Peterson, B., 1988. Financing constraints and corporate investments. Brooks Papers on Economic Activity 1, 141-195.

Gilchrist, S., Himmelberg, C., 1995. Evidence on the role of cash flow for investment, Journal of Monetary Economics 36, 541-572. 
Kaplan, S., Zingales, L., 1997. Do investment cash flow sensitivity provide useful measures of financing constraints? Quarterly Journal of Economics 112, 1, 169-215.

Povel, P., and Raith, M., 2003. Optimal investment under financial constraints: the roles of internal funds and asymmetric information. Working paper.

Ovtchinnikov, A,. (2010). Capital structure decisions: evidence from deregulated industries. Journal of Financial Economics, 95, 2, 249-278. 


\section{Appendix A1: Disclosure related provisions of the Sarbanes}

\section{Oxley Act}

Sarbanes Oxley Act implemented in 2002 is arranged into eleven sections. The most important sections pertaining to the quality and extent of disclosures are sections 302, 401, 404, 409, and 802.

\section{Summary of Section 302:}

Periodic statutory financial reports are to certify that:

- The report has been reviewed by the signing officers.

- The signing officers are responsible for internal controls. These officers have evaluated these internal controls within the previous ninety days and they have reported their findings.

- The report signed by the signing officers does not contain any false statements or is misleading. Further, the report should not have omitted any material.

- The financial statements and other reports depict the financial condition and the results of the firm reliably.

\section{Summary of Section 401:}

Financial statements published by issuers have to be correct. Further, the statements do not omit any material and are presented accurately.

\section{Summary of Section 404:}

The annual reports should have information regarding the adequacy and extent of the internal control systems and procedures for financial reporting. The effectiveness of such internal controls and procedures should be assessed and reported.

\section{Summary of Section 409:}


Issuers are required to disclose all the information when there are material changes in their financial condition or operations. These disclosures should be presented in a manner which is easy to understand and should be accurate to the fullest extent.

\section{Summary of Section 802:}

The issuers and the signing officers face punishments of fines and risk up to 20 years imprisonment for altering, destroying, mutilating, concealing, falsifying records, documents or tangible objects with the intent to obstruct, impede or influence a legal investigation. Any accountant who knowingly violates the requirements of the maintenance of all audit or review papers for a period of 5 years faces penalties of fines and/or imprisonment up to 10 years.

\section{Impact of SOX on Information Asymmetry}

The provisions of these sections improve the quality and extent of disclosures required by firms and is therefore expected to reduce the information asymmetry between the firm and the investors, as confirmed by the data. 


\section{Appendix A2: A summary of the relevant Deregulation Acts}

This Appendix provides brief summaries of the major Deregulation Acts enacted in the industry groups studied in this paper. Our industry definitions follow the Fama French industry codes which are very broad industry classifications containing multiple industry segments. It seems appropriate to use such a broad industry definition because as Ovtchinnikov (2009) points out, deregulation targeted at a particular industry segment is likely to impact all other segments in the industry group.

\section{Transportation Industry}

\section{Railroads and Trucking}

Pre-deregulation: The Interstate Commerce Act of 1887 established the Interstate Commerce Commission (ICC) which controlled the maximum rate, the minimum rate and the entry exit for the rail routes. ICC regulated the rail rates aggressively whereas the trucking rates were largely left in the hands of rate-making bureaus created by the trucking industries.

Deregulation: With the development of the interstate highways in 1950s, the railroads were facing increasing competition from the unregulated trucking industry, coupled with the fact that the railroads could not reduce the rates and could not exit the unprofitable routes. Under pressure from the railroads, the Railroad Revitalization and Regulatory Reforms Act of 1976(4R Act) was passed which allowed some flexibility to railroads to adjust rail rates. The Staggers Rail Act of 1980 overturned the Interstate Commerce Act of 1887 and gave the railroads almost complete freedom to choose rail rates and enter and exit. In 1975, ICC eased the entry to the trucking industry. The Motor Carrier Act of 1980 allowed unlimited entry in the trucking industry along with rate flexibility. 


\section{Airlines}

Pre-deregulation: The Civil Aeronautics Act of 1938 created Civil Aeronautics Authority, which came to be known as Civil Aeronautics Board (CAB). The CAB controlled the maximum rate, the minimum rate, the entry and exit and even the routes of airlines. Price regulation was the key regulation imposed by the $\mathrm{CAB}$ which strongly discouraged price competition. From 1938 to 1978 , CAB did not allow any other carrier to enter. Airlines could not compete on prices and hence competed with quality of service.

Deregulation: With the arrival of Alfred Kahn as the chairman of CAB, efforts to deregulate effort gained momentum. The first deregulation effort in July 1976 was aimed at reducing entry restrictions and fare controls. This was followed by Airline Deregulation Act of 1978. In a year, the airlines had full freedom to serve any route. By May 1980, the airlines had considerable upward flexibility and unlimited downward flexibility in determining fare.

\section{Communication Industry}

\section{Cable Television}

Pre-deregulation: The Communication Act of 1934 created the Federal Communications Commission (FCC) which had regulatory authority over wire and radio communications. In the 1950 s, local television channels were facing heavy competition from the cable television industry which was importing distant channels and not televising the local television broadcasts. On the request of television broadcasters, the FCC imposed heavy restrictions on cable television in 1962. The cable television industry was required to broadcast all the local television channels and was prevented from importing additional channels. The government offered franchises to cable companies televisions but also imposed rate regulation over the channels. 
Deregulation: In 1979 the price controls over pay channels were eliminated. The Cable Communication Act of 1984 eliminated federal, state or local regulation of basic cable services.

\section{Petroleum and Natural Gas Industry}

\section{Crude Oil}

Pre-deregulation: The Mandatory Oil Import Program (MOIP) which limited the import of foreign oil in order to reduce the dependence on foreign oil was implemented in 1959 by President Eisenhower. Price regulations were imposed on Crude Oil in the US when President Nixon imposed an economy wide price freeze in August of 1971 to reduce inflation. In November, 1973, with the Arab embargo on oil shipment to US, the pricing system was replaced by Emergency Petroleum Allocation Act (EPAA). This was replaced by Energy Policy and Conservation Act (EPCA) in December of 1975.

Deregulation: Restrictions on oil imports were loosened in 1970 and finally suspended in April, 1973. President Carter developed the first deregulation plan for the gradual decontrol of oil price from June 1979 to September 1981, when ECPA was allowed to expire. Further, he created the Windfall Profit Tax of 1980 which was an excise tax to prevent large transfer of wealth from the consumers to producers. President Regan lifted all remaining controls of oil price in Jan 1981 and repealed the Windfall Profit Tax in 1988.

\section{Natural Gas}

Pre-deregulation: Congress passed the Natural Gas Act of 1938 which gave Federal Power Commission (FPC) the power to regulate interstate transportation and sale of natural gas. Further the FPC controlled entry and gas prices. The price control of new and old gas 
discouraged new explorations.

Deregulation: The Natural Gas Policy Act of 1978 called for gradual decontrol of new gas prices. It also began loosening entry and exit restrictions. New gas price were to be brought to market clearing levels by 1985 . The price of the gas produced from deep wells was fully deregulated in November 1979 and new gas prices were fully deregulated in January 1985. Old gas price were fully deregulated in 1986 with FERC order 451.

\section{Impact of Deregulation on Information Asymmetry}

The provisions of the Deregulation Acts enacted in our industries of interest are largely aimed at lowering/eliminating barriers to entry and exit and loosening/eliminating price controls. These changes are expected to increase the firms' growth opportunities and also result in a more competitive and uncertain business environment. The information asymmetry is therefore expected to increase post-deregulation, as confirmed by the data. 
Table 1: Descriptive Statistics of Firm level variables: Event SOX

Investment is the capital expenditure. Cash flow is the sum of earnings before extraordinary items and depreciation. Both investment and cash flow are deflated by capital, which is net property, plant and equipment, at the beginning of the fiscal year. Tobin's Q is the market value of asset divided by the book value of asset. Market Value of asset is the sum of the book value of asset and market value of equity minus the sum of the book value of common equity and balance sheet deferred taxes. Market value of equity is the product of number of shares outstanding and price of the share at the fiscal year end. The data definition is from Kaplan and Zingales 1997. Event is SOX and event year is 2002. Pre is three years prior to the event, 1999, 2000 and 2001. Post is three years after the event, 2003, 2004and 2005. The variables reported here are three year averages of pre and post periods. The $p$ values for mean are for bootstrapped t tests. The $p$ values of the standard $t$ test are not reported here, but are similar to those of the bootstrapped t tests. The $p$ values for median are $p$ values for Wilcoxon Sign rank test.

\begin{tabular}{|c|c|c|c|c|c|c|}
\hline & \multicolumn{2}{|c|}{ Pre } & \multicolumn{2}{|c|}{ Post } & \multicolumn{2}{|c|}{ Difference } \\
\hline & Mean & Median & Mean & Median & Mean & Median \\
\hline $\begin{array}{l}\text { Investment/PP\&E } \\
\text { (p value) }\end{array}$ & 0.35 & 0.25 & 0.25 & 0.19 & $\begin{array}{r}-0.10 \\
(0.000)\end{array}$ & $\begin{array}{r}-0.04 \\
(0.000)\end{array}$ \\
\hline $\begin{array}{l}\text { Tobin's Q } \\
\text { (p value) }\end{array}$ & 2.36 & 1.64 & 1.88 & 1.51 & $\begin{array}{r}-0.52 \\
(0.000)\end{array}$ & $\begin{array}{r}-0.09 \\
(0.000)\end{array}$ \\
\hline $\begin{array}{l}\text { Cash Flow/PP\&E } \\
\text { (p value) }\end{array}$ & 0.14 & 0.32 & 0.25 & 0.32 & $\begin{array}{r}0.15 \\
(0.009)\end{array}$ & $\begin{array}{r}0.01 \\
(0.091)\end{array}$ \\
\hline $\begin{array}{l}\text { Size } \\
\text { (p value) }\end{array}$ & 2607.88 & 534.40 & 3241.84 & 748.97 & $\begin{array}{l}633.96 \\
(0.000)\end{array}$ & $\begin{array}{l}214.57 \\
(0.000)\end{array}$ \\
\hline $\mathrm{N}$ & 1681 & 1681 & 1730 & 1730 & 1610 & 1610 \\
\hline
\end{tabular}




\begin{tabular}{|c|c|c|c|c|c|c|}
\hline & \multicolumn{2}{|c|}{ Pre } & \multicolumn{2}{|c|}{ Post } & \multicolumn{2}{|c|}{ Difference } \\
\hline & Mean & Median & Mean & Median & Mean & Median \\
\hline $\begin{array}{l}\text { Investment/PP\&E } \\
\text { (p value) }\end{array}$ & 0.31 & 0.23 & 0.24 & 0.19 & $\begin{array}{r}-0.07 \\
(0.000)\end{array}$ & $\begin{array}{r}-0.03 \\
(0.000)\end{array}$ \\
\hline $\begin{array}{l}\text { Tobin's Q } \\
\text { (p value) }\end{array}$ & 2.13 & 1.55 & 1.83 & 1.49 & $\begin{array}{r}-0.35 \\
(0.000)\end{array}$ & $\begin{array}{r}-0.04 \\
(0.000)\end{array}$ \\
\hline $\begin{array}{l}\text { Cash Flow/PP\&E } \\
\text { (p value) }\end{array}$ & 0.64 & 0.38 & 0.66 & 0.40 & $\begin{array}{r}0.01 \\
(0.672)\end{array}$ & $\begin{array}{r}0.01 \\
(0.156)\end{array}$ \\
\hline $\begin{array}{l}\text { Size } \\
\text { (p value) }\end{array}$ & 2829.39 & 659.35 & 3584.62 & 894.27 & $\begin{array}{l}755.23 \\
(0.000)\end{array}$ & $\begin{array}{l}234.92 \\
(0.000)\end{array}$ \\
\hline $\mathrm{N}$ & 1468 & 1468 & 1481 & 1481 & 1300 & 1300 \\
\hline
\end{tabular}

\begin{tabular}{|c|c|c|c|c|c|c|}
\hline & \multicolumn{2}{|c|}{ Pre } & \multicolumn{2}{|c|}{ Post } & \multicolumn{2}{|c|}{ Difference } \\
\hline & Mean & Median & Mean & Median & Mean & Median \\
\hline $\begin{array}{l}\text { Investment/PP\&E } \\
\text { (p value) }\end{array}$ & 0.58 & 0.42 & 0.30 & 0.18 & $\begin{array}{r}-0.29 \\
(0.000)\end{array}$ & $\begin{array}{r}-0.22 \\
(0.000)\end{array}$ \\
\hline $\begin{array}{l}\text { Tobin's Q } \\
\text { (p value) }\end{array}$ & 3.96 & 3.11 & 2.14 & 1.63 & $\begin{array}{r}-1.94 \\
(0.000)\end{array}$ & $\begin{array}{r}-1.17 \\
(0.001)\end{array}$ \\
\hline $\begin{array}{l}\text { Cash Flow/PP\&E } \\
\text { (p value) }\end{array}$ & -3.33 & -1.22 & -2.22 & -0.62 & $\begin{array}{r}0.79 \\
(0.260)\end{array}$ & $\begin{array}{r}0.56 \\
(0.001)\end{array}$ \\
\hline $\begin{array}{l}\text { Size } \\
\text { (p value) }\end{array}$ & 1081.26 & 185.69 & 1203.03 & 278.92 & $\begin{array}{r}0.09 \\
(0.183)\end{array}$ & $\begin{array}{r}0.01 \\
(0.320)\end{array}$ \\
\hline $\mathrm{N}$ & 213 & 213 & 249 & 249 & 105 & 105 \\
\hline
\end{tabular}


Table 2 : Descriptive Statistics of Information Asymmetry Variables: Event SOX

Panel A: Mkt Res is calculated as the residual of regressing a firm's daily stock return on value weighted market index. Mkt Res/ Tot Var is calculated as the ratio of market residuals to total variance. Mkt Res and Mkt/ Tot Var reported here are three year averages based on pre and post periods.

Panel B: Bid Ask spread is calculated on a yearly basis using the methodology of Corwin and Schultz. The numbers reported here are three year averages based on pre and post period.

Event is SOX and event year is 2002. Pre is three years prior to the event, 1999, 2000 and 2001. Post is three years after the event, 2003, 2004 and 2005. The numbers reported here are three year averages based on pre and post period. The $\mathrm{p}$ values for means are for bootstrapped t tests. The $\mathrm{p}$ values of the standard t test are not reported here, but are similar to the boot strapped t tests. The $\mathrm{p}$ values for median are $\mathrm{p}$ values for Wilcoxon Sign rank test.

\begin{tabular}{|c|c|c|c|c|c|c|}
\hline \multicolumn{7}{|l|}{ Panel A: All Firms } \\
\hline & \multicolumn{2}{|c|}{ Pre } & \multicolumn{2}{|c|}{ Post } & \multicolumn{2}{|c|}{ Post - Pre } \\
\hline & Mean & Median & Mean & Median & Mean & Median \\
\hline $\begin{array}{l}\text { Mkt Res } \\
\text { (p value) }\end{array}$ & $3.75 \%$ & $3.30 \%$ & $2.14 \%$ & $1.80 \%$ & $\begin{array}{l}-1.61 \% \\
(0.000)\end{array}$ & $\begin{array}{l}-1.43 \% \\
(0.000)\end{array}$ \\
\hline $\begin{array}{l}\text { Mkt Res / Tot Var } \\
\text { (p value) }\end{array}$ & $84.82 \%$ & $87.47 \%$ & $80.61 \%$ & $82.13 \%$ & $\begin{array}{l}-4.49 \% \\
(0.000)\end{array}$ & $\begin{array}{l}-4.37 \% \\
(0.000)\end{array}$ \\
\hline $\mathrm{N}$ & 1681 & 1681 & 1730 & 1730 & 1610 & 1610 \\
\hline $\begin{array}{l}\text { Bid Ask Spread } \\
\text { ( p value) }\end{array}$ & $0.733 \%$ & $0.607 \%$ & $0.386 \%$ & $0.312 \%$ & $\begin{array}{r}-0.352 \% \\
(0.000)\end{array}$ & $\begin{array}{r}-0.291 \% \\
(0.000)\end{array}$ \\
\hline $\mathrm{N}$ & 1639 & 1639 & 1689 & 1689 & 1568 & 1568 \\
\hline
\end{tabular}




\begin{tabular}{|c|c|c|c|c|c|c|}
\hline \multicolumn{7}{|c|}{ Panel B : All Positive Cash Flow Firms } \\
\hline & \multicolumn{2}{|c|}{ Pre } & \multicolumn{2}{|c|}{ Post } & \multicolumn{2}{|c|}{ Post - Pre } \\
\hline & Mean & Median & Mean & Median & Mean & Median \\
\hline $\begin{array}{l}\text { Mkt Res } \\
\text { (p value) }\end{array}$ & $3.46 \%$ & $3.17 \%$ & $1.89 \%$ & $1.70 \%$ & $\begin{array}{l}-1.53 \% \\
(0.000)\end{array}$ & $\begin{array}{l}-1.38 \% \\
(0.000)\end{array}$ \\
\hline $\begin{array}{l}\text { Mkt Res / Tot Var } \\
\text { (p value) }\end{array}$ & $84.80 \%$ & $87.12 \%$ & $80.14 \%$ & $81.50 \%$ & $\begin{array}{l}-5.02 \% \\
(0.000)\end{array}$ & $\begin{array}{l}-4.73 \% \\
(0.000)\end{array}$ \\
\hline $\mathrm{N}$ & 1468 & 1468 & 1481 & 1481 & 1300 & 1300 \\
\hline $\begin{array}{l}\text { Bid Ask Spread } \\
\text { ( p value) }\end{array}$ & $0.687 \%$ & $0.575 \%$ & $0.342 \%$ & $0.286 \%$ & $\begin{array}{r}-0.345 \% \\
(0.000)\end{array}$ & $\begin{array}{r}-0.286 \% \\
(0.000)\end{array}$ \\
\hline $\mathrm{N}$ & 1434 & 1434 & 1443 & 1443 & 1263 & 1263 \\
\hline
\end{tabular}

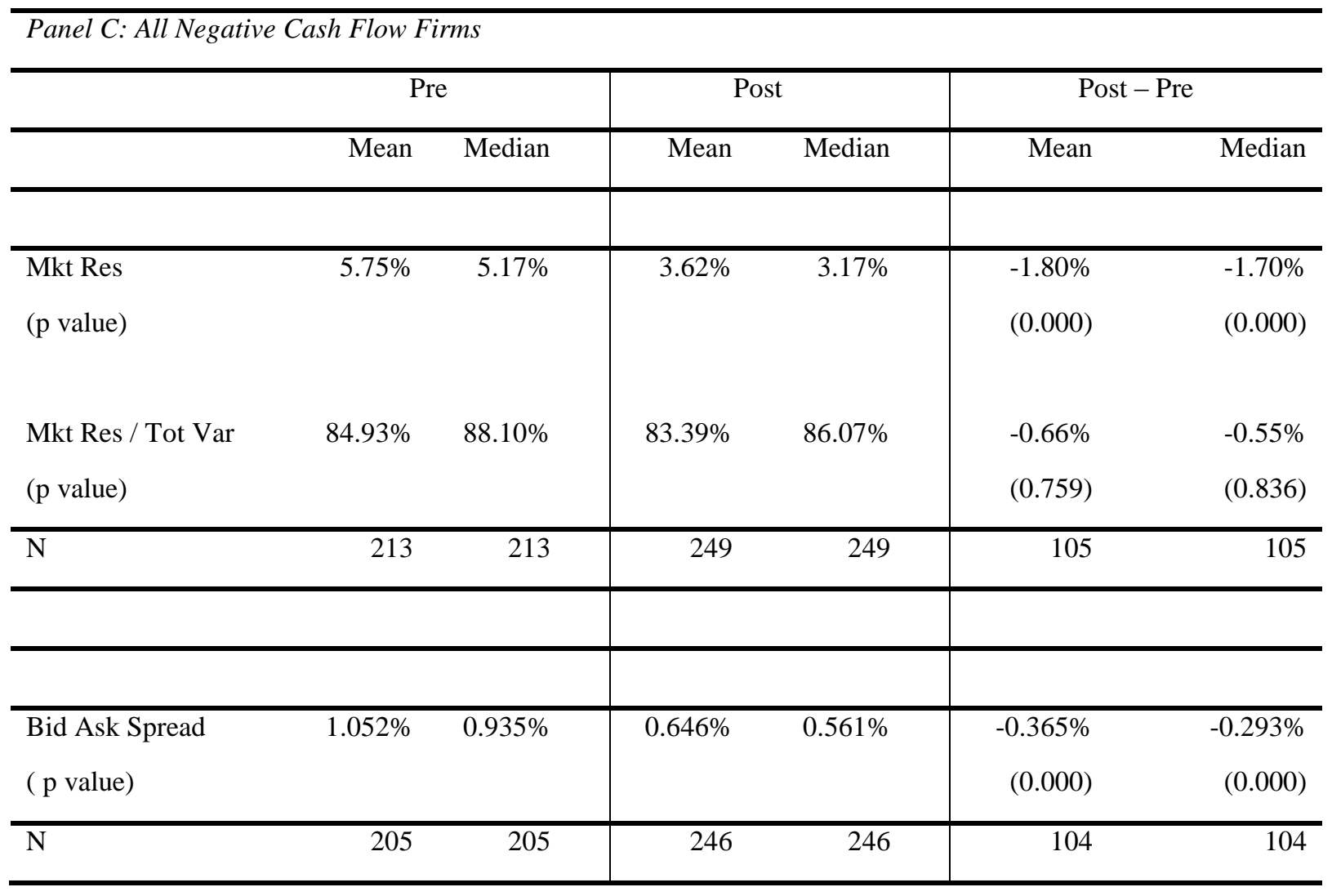


Table 3 : Regression of Investment on Cash Flow and Tobin's Q: Event SOX

Investment is capital expenditure and is the dependent variable. Cash flow is the sum of earnings before extraordinary items and depreciation. Both investment and cash flow are deflated by capital, which is net property, plant and equipment, at the beginning of the fiscal year. Tobin's Q is the market value of asset divided by the book value of asset. Market Value of asset is the sum of the book value of asset and market value of equity minus the sum of the book value of common equity and balance sheet deferred taxes. Market value of equity is the product of number of shares outstanding and price of the share at the fiscal year end. The data definition is from Kaplan and Zingales 1997. Event is SOX and event year is 2002. Pre is three years prior to the event, 1999, 2000 and 2001. Post is three years after the event, 2003, 2004 and 2005. SOX_DUM is 0 for pre SOX period and 1 for post SOX period. Every firm has one observation for the pre period, one observation for the post period, the observation being the average of the pre and the post period respectively. The second entry is the corresponding $t$ statistics. The second entry for Chow Fisher F test and Chow test are the $\mathrm{p}$ values.

\begin{tabular}{lrrr}
\hline Panel A: All Positive Cash Flow Firms & & & \\
\hline & Pre & Post & Pooled \\
\hline Intercept & 0.12 & 0.11 & 0.12 \\
& 12.47 & 13.27 & \\
& & & 0.05 \\
Tobin's Q & 0.05 & 0.04 & 15.76 \\
& 13.64 & 9.58 & \\
& & & 0.13 \\
Cash Flow & 0.13 & 0.09 & 20.73
\end{tabular}

$\begin{array}{lr}\text { SOX_Dum } & -0.01\end{array}$

$\begin{array}{lr}\text { SOX_DumxCashFlow } & -0.05\end{array}$

SOX_DumxTobin's Q

\begin{tabular}{lccr}
\hline $\mathrm{N}$ & 1468 & 1481 & 2949 \\
\hline $\mathrm{R}^{2}$ & 0.34 & 0.28 & 0.34 \\
\hline
\end{tabular}




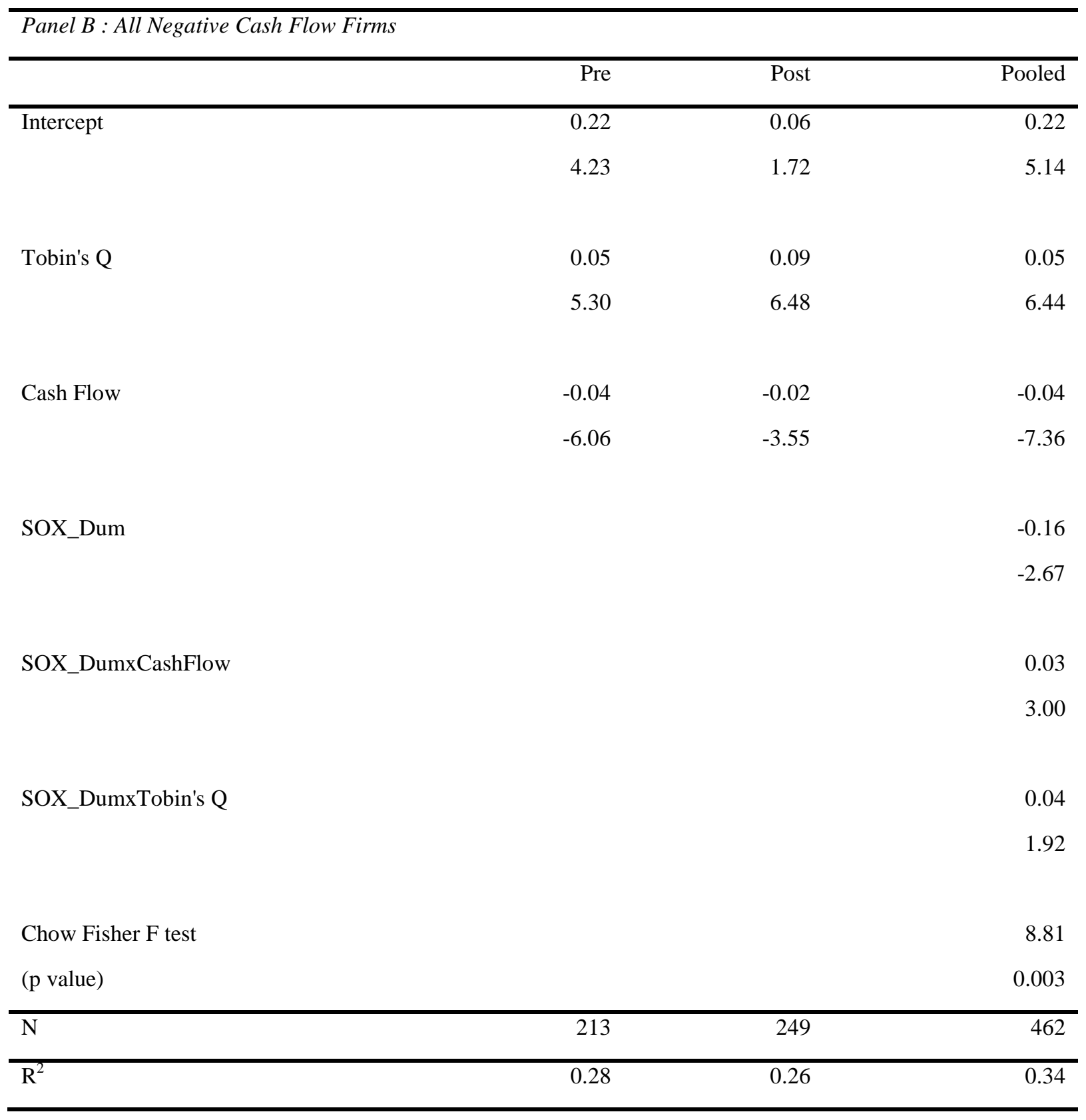


Table 4 : Regression of Investment on Cash Flow and Tobin's $Q$ with a control variable for misvaluation: Event SOX

Investment is capital expenditure and is the dependent variable. Cash flow is the sum of earnings before extraordinary items and depreciation. Both investment and cash flow are deflated by capital, which is net property, plant and equipment, at the beginning of the fiscal year. Tobin's Q is the market value of asset divided by the book value of asset. Market Value of asset is the sum of the book value of asset and market value of equity minus the sum of the book value of common equity and balance sheet deferred taxes. Market value of equity is the product of number of shares outstanding and price of the share at the fiscal year end. The data definition is from Kaplan and Zingales 1997. We calculate intrinsic value of the firm's assets using analyst forecast. Misvaluation is defined as the ratio of market equity to intrinsic value of the firm. Event is SOX and event year is 2002. Pre is three years prior to the event, 1999, 2000 and 2001. Post is three years after the event, 2003, 2004 and 2005. SOX_DUM is 0 for pre SOX period and 1 for post SOX period. Every firm has one observation for the pre period, one observation for the post period, the observation being the average of the pre and the post period respectively. The second entry is the corresponding t statistics. The second entry for Chow Fisher $\mathrm{F}$ test is the $\mathrm{p}$ value. 


\begin{tabular}{|c|c|c|c|}
\hline & Pre & Post & Pooled \\
\hline \multirow[t]{2}{*}{ Intercept } & 0.16 & 0.11 & 0.16 \\
\hline & 13.14 & 9.56 & 14.33 \\
\hline \multirow[t]{2}{*}{ Tobin's Q } & 0.04 & 0.04 & 0.04 \\
\hline & 8.94 & 6.48 & 9.75 \\
\hline \multirow[t]{2}{*}{ Cash Flow } & 0.13 & 0.09 & 0.13 \\
\hline & 14.90 & 13.04 & 16.25 \\
\hline \multirow[t]{2}{*}{ Misvaluation $\left(10^{-2}\right)$} & 0.10 & 0.31 & 0.00 \\
\hline & 1.24 & 4.20 & 1.35 \\
\hline \multirow[t]{2}{*}{ SOX_Dum } & & & -0.05 \\
\hline & & & -2.80 \\
\hline \multirow[t]{2}{*}{ SOX_DumxCashFlow } & & & -0.04 \\
\hline & & & -3.57 \\
\hline \multirow[t]{2}{*}{ SOX_DumxTobin's Q } & & & -0.01 \\
\hline & & & -0.69 \\
\hline \multirow[t]{2}{*}{ SOX_DumxMisvaluation $\left(10^{-2}\right)$} & & & 0.21 \\
\hline & & & 1.95 \\
\hline Chow Fisher F test & & & 12.69 \\
\hline (p value) & & & 0.000 \\
\hline $\mathrm{N}$ & 862 & 862 & 1724 \\
\hline$\overline{\mathrm{R}^{2}}$ & 0.340 & 0.307 & 0.348 \\
\hline
\end{tabular}


Table 5 : Regression of Investment on Cash Flow and Tobin's Q based on asymmetric information proxy market residual/ total variance: Event SOX.

Mkt Res/ Tot Var is the ratio of market residuals to total variance. Mkt/ Tot Var is calculated on a yearly basis. The numbers reported in the first three columns are three year average of Mkt Res/Tot Var based on pre and post period and the difference between post and pre periods. The $\mathrm{p}$ values of bootstrapped tests are reported here. The $\mathrm{p}$ values of the standard t test are similar. Event is SOX and event year is 2002. Pre is three years prior to the event, 1999, 2000 and 2001. Post is three years after the event, 2003, 2004 and 2005.

Investment is capital expenditure and is the dependent variable. Cash flow is the sum of earnings before extraordinary items and depreciation. Both investment and cash flow are deflated by capital, which is net property, plant and equipment, at the beginning of the fiscal year. Tobin's Q is the market value of asset divided by the book value of asset. Market Value of asset is the sum of the book value of asset and market value of equity minus the sum of the book value of common equity and balance sheet deferred taxes. Market value of equity is the product of number of shares outstanding and price of the share at the fiscal year end. . SOX_DUM is 0 for pre SOX period and 1 for post SOX period. The data definition is from Kaplan and Zingales 1997.The second entries are the corresponding $t$ statistics. The second entry for the Chow Fisher $\mathrm{T}$ test is the corresponding $\mathrm{p}$ value. 


\begin{tabular}{|c|c|c|c|c|c|c|c|c|c|}
\hline & \multicolumn{3}{|c|}{ First Tercile } & \multicolumn{3}{|c|}{ Second Tercile } & \multicolumn{3}{|c|}{ Third Tercile } \\
\hline & Pre & Post & Pooled & Pre & Post & Pooled & Pre & Post & Pooled \\
\hline \multicolumn{10}{|c|}{ Panel A: Descriptive Statistics } \\
\hline Mean & $87.80 \%$ & $68.54 \%$ & & $88.80 \%$ & $83.64 \%$ & & $78.01 \%$ & $87.38 \%$ & \\
\hline Mean Difference & \multicolumn{2}{|c|}{$-19.27 \%$} & & \multicolumn{2}{|c|}{$-5.16 \%$} & \multicolumn{4}{|c|}{$9.37 \%$} \\
\hline (p value) & \multicolumn{2}{|c|}{$(0.000)$} & & \multicolumn{2}{|c|}{$(0.000)$} & \multicolumn{4}{|c|}{$(0.000)$} \\
\hline \multicolumn{10}{|c|}{ Panel B :Regression results } \\
\hline \multirow[t]{2}{*}{ Intercept } & 0.11 & 0.12 & 0.11 & 0.14 & 0.13 & 0.14 & 0.14 & 0.10 & 0.14 \\
\hline & 8.04 & 8.24 & 8.76 & 6.85 & 10.27 & 8.48 & 9.25 & 6.39 & 10.82 \\
\hline \multirow[t]{2}{*}{ Tobin's Q } & 0.04 & 0.03 & 0.04 & 0.03 & 0.03 & 0.03 & 0.05 & 0.03 & 0.05 \\
\hline & 8.35 & 3.90 & 9.10 & 3.14 & 3.93 & 3.89 & 7.46 & 3.63 & 8.73 \\
\hline \multirow[t]{2}{*}{ Cash Flow } & 0.10 & 0.06 & 0.10 & 0.16 & 0.08 & 0.16 & 0.12 & 0.13 & 0.12 \\
\hline & 9.76 & 8.48 & 10.63 & 10.19 & 11.22 & 12.61 & 10.43 & 11.29 & 12.20 \\
\hline \multirow[t]{2}{*}{ SOX_Dum } & & & 0.01 & & & -0.01 & & & -0.04 \\
\hline & & & 0.44 & & & -0.21 & & & -1.71 \\
\hline \multirow[t]{2}{*}{ SOX_DumxCash Flow } & & & -0.04 & & & -0.09 & & & 0.01 \\
\hline & & & -3.01 & & & -5.26 & & & 0.32 \\
\hline \multirow[t]{2}{*}{ SOX_DumxTobin'sQ } & & & -0.02 & & & 0.00 & & & -0.01 \\
\hline & & & -1.62 & & & -0.15 & & & -0.90 \\
\hline Chow Fisher F Test & & & 9.02 & & & 27.47 & & & 0.10 \\
\hline ( $\mathrm{p}$ value) & & & 0.002 & & & 0.000 & & & 0.747 \\
\hline $\bar{N}$ & 433 & 433 & 866 & 434 & 434 & 868 & 433 & 433 & 866 \\
\hline$\overline{\mathrm{R}^{2}}$ & 0.334 & 0.199 & 0.298 & 0.253 & 0.294 & 0.276 & 0.382 & 0.333 & 0.391 \\
\hline
\end{tabular}




\section{Table 6 : Descriptive Statistics of the sample firms: Event Deregulation}

Investment is capital expenditure. Cash flow is the sum of earnings before extraordinary items and depreciation. Both investment and cash flow are deflated by capital, which is net property, plant and equipment, at the beginning of the fiscal year. Tobin's Q is the market value of asset divided by the book value of asset. Market Value of asset is the sum of the book value of asset and market value of equity minus the sum of the book value of common equity and balance sheet deferred taxes. Market value of equity is the product of number of shares outstanding and price of the share at the fiscal year end. The data definition is from Kaplan and Zingales 1997.Pre is a period of 3 years, which are 1 year prior to the event year, 2 years prior to the event year and 3 years prior to the event year. Post is a period of three years, which are 1 year after the event year, 2 years after the event year and 3 years after the event year. In column 5 and 6, the first entry is the mean(median). Difference in mean is tested by standard t test and the difference in median is tested by Wilcoxon sign rank test. The second entry of Column 5 reports $\mathrm{p}$ value of the bootstrapped t test. The second entry in column 6 is the $\mathrm{p}$ value of the Wilcoxon Signed rank test.

\begin{tabular}{|c|c|c|c|c|c|c|}
\hline & \multicolumn{2}{|c|}{ Pre } & \multicolumn{2}{|c|}{ Post } & \multicolumn{2}{|c|}{ Difference } \\
\hline & Mean & Median & Mean & Median & Mean & Median \\
\hline Investment/PP\&E & 0.31 & 0.29 & 0.39 & 0.37 & 0.08 & 0.07 \\
\hline ( $\mathrm{p}$ value) & & & & & $(0.000)$ & $(0.000)$ \\
\hline Tobin's Q & 1.12 & 1.01 & 1.41 & 1.15 & 0.26 & 0.13 \\
\hline (p value) & & & & & $(0.000)$ & $(0.000)$ \\
\hline Cash Flow/PP\&E & 0.30 & 0.26 & 0.32 & 0.29 & 0.01 & 0.01 \\
\hline ( $\mathrm{p}$ value) & & & & & $(0.493)$ & $(0.134)$ \\
\hline Total Asset & 1200.71 & 172.48 & 2592.48 & 460.29 & 1224.50 & 163.15 \\
\hline ( $\mathrm{p}$ value) & & & & & $(0.066)$ & $(0.000)$ \\
\hline Mkt Res & $1.47 \%$ & $1.28 \%$ & $1.80 \%$ & $1.70 \%$ & $0.38 \%$ & $0.23 \%$ \\
\hline ( $p$ value) & & & & & $(0.001)$ & $(0.009)$ \\
\hline Mkt Res/Tot Var & $58.35 \%$ & $59.40 \%$ & $64.63 \%$ & $66.77 \%$ & $7.02 \%$ & $8.52 \%$ \\
\hline ( $\mathrm{p}$ value) & & & & & $(0.028)$ & $(0.012)$ \\
\hline Bid Ask Spread & $1.59 \%$ & $1.47 \%$ & $0.18 \%$ & $1.63 \%$ & $0.27 \%$ & $0.07 \%$ \\
\hline (p value) & & & & & $(0.022)$ & $(0.220)$ \\
\hline $\mathrm{N}$ & 159 & 159 & 132 & 132 & 132 & 132 \\
\hline
\end{tabular}


Table 7 : Descriptive statistics of the control firms: Event Deregulation

Investment is capital expenditure. Cash flow is the sum of earnings before extraordinary items and depreciation. Both investment and cash flow are deflated by capital, which is net property, plant and equipment, at the beginning of the fiscal year. Tobin's Q is the market value of asset divided by the book value of asset. Market Value of asset is the sum of the book value of asset and market value of equity minus the sum of the book value of common equity and balance sheet deferred taxes. Market value of equity is the product of number of shares outstanding and price of the share at the fiscal year end. The data definition is from Kaplan and Zingales 1997. Pre is a period of 3 years, which are 1 year prior to the event year, 2 years prior to the event year and 3 years prior to the event year. Post is a period of three years, which are 1 year after the event year, 2 years after the event year and 3 years after the event year. In column 5 and 6, the first entry is the mean (median). Difference in mean is tested by standard t test and the difference in median is tested by Wilcoxon sign rank test. The second entry of Column 5 reports $\mathrm{p}$ value of the t test. The second entry in column 6 is the p value of the Wilcoxon Signed rank test.

\begin{tabular}{|c|c|c|c|c|c|c|}
\hline & \multicolumn{2}{|c|}{ Pre } & \multicolumn{2}{|c|}{ Post } & \multicolumn{2}{|c|}{ Difference } \\
\hline & Mean & Median & Mean & Median & Mean & Median \\
\hline Investment/PP\&E & 0.29 & 0.25 & 0.27 & 0.25 & -0.02 & -0.01 \\
\hline ( $\mathrm{p}$ value) & & & & & $(0.315)$ & $(0.586)$ \\
\hline Tobin's Q & 1.15 & 0.99 & 1.09 & 0.98 & -0.08 & -0.04 \\
\hline (p value) & & & & & $(0.155)$ & $(0.002)$ \\
\hline Cash Flow/PP\&E & 0.31 & 0.28 & 0.32 & 0.28 & 0.00 & -0.01 \\
\hline ( $\mathrm{p}$ value) & & & & & $(0.960)$ & $(0.784)$ \\
\hline Total Asset & 747.16 & 169.10 & 1311.75 & 345.72 & 470.10 & 93.53 \\
\hline ( $\mathrm{p}$ value) & & & & & $(0.110)$ & $(0.000)$ \\
\hline Mkt Res & $1.68 \%$ & $1.40 \%$ & $1.69 \%$ & $1.43 \%$ & $-0.07 \%$ & $-0.05 \%$ \\
\hline ( $p$ value) & & & & & $(0.608)$ & $(0.991)$ \\
\hline Mkt Res/ Tot Var & $63.65 \%$ & $68.42 \%$ & $60.96 \%$ & $67.37 \%$ & $-2.46 \%$ & $6.15 \%$ \\
\hline ( $\mathrm{p}$ value) & & & & & $(0.705)$ & $(0.23)$ \\
\hline Bid Ask Spread & $1.80 \%$ & $1.57 \%$ & $1.77 \%$ & $1.52 \%$ & $-0.03 \%$ & $0.00 \%$ \\
\hline ( $\mathrm{p}$ value) & & & & & $(0.837)$ & $(0.233)$ \\
\hline $\mathrm{N}$ & 159 & 159 & 132 & 132 & 132 & 132 \\
\hline
\end{tabular}


Investment is capital expenditure. Cash flow is the sum of earnings before extraordinary items and depreciation. Both investment and cash flow are deflated by capital, which is net property, plant and equipment, at the beginning of the fiscal year. Tobin's Q is the market value of asset divided by the book value of asset. Market Value of asset is the sum of the book value of asset and market value of equity minus the sum of the book value of common equity and balance sheet deferred taxes. Market value of equity is the product of number of shares outstanding and price of the share at the fiscal year end. The data definition is from Kaplan and Zingales 1997. Pre is a period of 3 years, which are 1 year prior to the event year, 2 years prior to the event year and 3 years prior to the event year. Post is a period of three years, which are 1 year after the event year, 2 years after the event year and 3 years after the event year. In column 1 and 2, we document the difference in mean and median between the sample and control firms for different variables in the pre years. In column 3 and 4, again the same exercise is conducted for the post years. In columns 5 and 6 , we document the difference between the entry in column 2 and column 1 . Column 5 and 6 documents the difference between post year difference between the sample and control and pre year difference between sample and control.

\begin{tabular}{|c|c|c|c|c|c|c|}
\hline & \multicolumn{2}{|c|}{ Pre } & \multicolumn{2}{|c|}{ Post } & \multicolumn{2}{|l|}{ Post - Pre } \\
\hline & Mean & Median & Mean & Median & Mean & Median \\
\hline Investment/PP\&E & 0.01 & 0.02 & 0.12 & 0.10 & 0.10 & 0.08 \\
\hline (p value) & $(0.473)$ & $(0.214)$ & $(0.000)$ & $(0.000)$ & $(0.000)$ & $(0.000)$ \\
\hline Tobin's Q & -0.03 & -0.01 & 0.32 & 0.12 & 0.34 & 0.16 \\
\hline (p value) & $(0.537)$ & $(0.237)$ & $(0.000)$ & $(0.000)$ & $(0.000)$ & $(0.000)$ \\
\hline Cash Flow/PP\&E & -0.02 & -0.01 & 0.00 & 0.00 & 0.02 & 0.02 \\
\hline (p value) & $(0.270)$ & $(0.153)$ & $(0.877)$ & $(0.967)$ & $(0.445)$ & $(0.106)$ \\
\hline Total Asset & 453.60 & 0.95 & 1280.70 & 34.18 & 754.30 & 33.92 \\
\hline ( $\mathrm{p}$ value) & $(0.114)$ & $(0.813)$ & $(0.047)$ & $(0.000)$ & $(0.282)$ & $(0.000)$ \\
\hline Mkt Res & $-0.22 \%$ & $-0.10 \%$ & $0.11 \%$ & $0.10 \%$ & $0.42 \%$ & $0.40 \%$ \\
\hline ( $\mathrm{p}$ value) & $(0.0851)$ & $(0.214)$ & $(0.488)$ & $(0.211)$ & $(0.013)$ & $(0.043)$ \\
\hline Mkt Res/Tot Var & $-5.30 \%$ & $-9.75 \%$ & $3.67 \%$ & $-2.81 \%$ & $12.98 \%$ & $10.50 \%$ \\
\hline ( $\mathrm{p}$ value) & $(0.109)$ & $(0.002)$ & $(0.556)$ & $(0.203)$ & $(0.103)$ & $(0.100)$ \\
\hline Bid Ask Spread & $-0.20 \%$ & $-0.20 \%$ & $0.07 \%$ & $0.10 \%$ & $0.40 \%$ & $0.35 \%$ \\
\hline (p value) & $(0.131)$ & $(0.456)$ & $(0.611)$ & $(0.121)$ & $(0.013)$ & $(0.014)$ \\
\hline $\bar{N}$ & 159 & 159 & 132 & 132 & 132 & 132 \\
\hline
\end{tabular}


Investment is capital expenditure. Cash flow is the sum of earnings before extraordinary items and depreciation. Both investment and cash flow are deflated by capital, which is net property, plant and equipment, at the beginning of the fiscal year. Tobin's Q is the market value of asset divided by the book value of asset. Market Value of asset is the sum of the book value of asset and market value of equity minus the sum of the book value of common equity and balance sheet deferred taxes. Market value of equity is the product of number of shares outstanding and price of the share at the fiscal year end. The data definition is from Kaplan and Zingales 1997. Dum is the dummy variable which takes the value of 1 for post deregulation periods.

Average investment is the time series average of investment per firm. So every firm has one value of investment, which is the average of investment over time for that firm. Same is true for average Tobin's Q and average cash flow. Column 1 and 2 report the regression of average investment on average Q and average cash flow for pre and post periods respectively. Third column reports the Chow-Fisher test result. The first entry for all the columns is the regression coefficient and the second column is the corresponding $t$ value. For the ChowFisher test in column 3, the first entry is the F statistics and the second entry is the corresponding $\mathrm{p}$ value. 


\begin{tabular}{|c|c|c|c|c|}
\hline & Pre & Post & Pooled 1 & Pooled2 \\
\hline \multirow[t]{2}{*}{ Intercept } & 0.13 & 0.17 & 0.13 & 0.16 \\
\hline & 3.64 & 4.50 & 3.31 & 6.51 \\
\hline \multirow[t]{2}{*}{ Tobin's Q } & 0.12 & 0.08 & 0.12 & 0.09 \\
\hline & 3.49 & 3.92 & 3.17 & 5.32 \\
\hline \multirow[t]{2}{*}{ Cash Flow } & 0.14 & 0.34 & 0.14 & 0.16 \\
\hline & 1.79 & 3.97 & 1.63 & 2.58 \\
\hline \multirow[t]{2}{*}{ Dereg_Dum } & & & 0.03 & \\
\hline & & & 0.64 & \\
\hline \multirow[t]{2}{*}{ Dereg_DumxCashFlow } & & & 0.21 & 0.18 \\
\hline & & & 1.81 & 3.31 \\
\hline \multirow[t]{2}{*}{ Dereg_DumxTobin'sQ } & & & -0.04 & \\
\hline & & & -0.85 & \\
\hline Chow Fisher F test & & & 3.27 & \\
\hline (p value) & & & 0.071 & \\
\hline Chow Test & & & & 3.79 \\
\hline (p value) & & & & 0.010 \\
\hline $\mathrm{N}$ & 159 & 132 & 291 & 291 \\
\hline$\overline{R^{2}}$ & 0.129 & 0.242 & 0.239 & 0.243 \\
\hline
\end{tabular}


Investment is capital expenditure. Cash flow is the sum of earnings before extraordinary items and depreciation. Both investment and cash flow are deflated by capital, which is net property, plant and equipment, at the beginning of the fiscal year. Tobin's Q is the market value of asset divided by the book value of asset. Market Value of asset is the sum of the book value of asset and market value of equity minus the sum of the book value of common equity and balance sheet deferred taxes. Market value of equity is the product of number of shares outstanding and price of the share at the fiscal year end. The data definition is from Kaplan and Zingales 1997. Dum is the dummy variable which takes the value of 1 for post deregulation periods.

Average investment is the time series average of investment per firm. So every firm has one value of investment, which is the average of investment over time for that firm. Same is true for average Tobin's Q and average cash flow. Column 1 and 2 report the regression of average investment on average $\mathrm{Q}$ and average cash flow for pre and post periods respectively. Third column reports the Chow-Fisher test result. The first entry for all the columns is the regression coefficient and the second column is the corresponding $t$ value. For the ChowFisher test in column 3, the first entry is the F statistics and the second entry is the corresponding p value. 


\begin{tabular}{|c|c|c|c|c|}
\hline & Pre & Post & Pooled 1 & Pooled2 \\
\hline \multirow[t]{2}{*}{ Intercept } & 0.14 & 0.13 & 0.14 & 0.14 \\
\hline & 4.34 & 2.46 & 4.97 & 6.05 \\
\hline \multirow[t]{2}{*}{ Tobin's Q } & 0.00 & 0.06 & 0.00 & 0.02 \\
\hline & 0.02 & 2.07 & 0.02 & 0.99 \\
\hline \multirow[t]{2}{*}{ Cash Flow } & 0.47 & 0.22 & 0.47 & 0.41 \\
\hline & 5.79 & 2.98 & 6.62 & 6.92 \\
\hline \multirow[t]{2}{*}{ Dereg_Dum } & & & -0.01 & \\
\hline & & & -0.17 & \\
\hline \multirow[t]{2}{*}{ Dereg_DumxCashFlow } & & & -0.26 & -0.10 \\
\hline & & & -2.26 & -2.14 \\
\hline \multirow[t]{2}{*}{ Dereg_DumxTobin'sQ } & & & 0.06 & \\
\hline & & & 1.34 & \\
\hline Chow Fisher F test & & & 5.13 & \\
\hline (p value) & & & 0.017 & \\
\hline Chow Test & & & & 3.08 \\
\hline (p value) & & & & 0.027 \\
\hline $\mathrm{N}$ & 159 & 132 & 291 & 291 \\
\hline$\overline{R^{2}}$ & 0.209 & 0.120 & 0.189 & 0.187 \\
\hline
\end{tabular}


Market Residual is calculated as the residual of regressing a firm's daily stock return on value weighted market index. Market Residual/total variance is the ratio of the market residual to the total variance of the stock price of the firm. Market residual / total variance is calculated on a yearly basis. The pre value of Market residual / total variance is the three year average of market residual / total variance of the sample over the pre period. The post value of market residual is calculated as the three year average market residual /total variance of the sample firms. The $\mathrm{p}$ value of bootstrapped t test is reported here. Event is industry level deregulation. Pre is three years prior to the event. Post is three years after the event.

Investment is capital expenditure and is the dependent variable. Cash flow is the sum of earnings before extraordinary items and depreciation. Both investment and cash flow are deflated by capital, which is net property, plant and equipment, at the beginning of the fiscal year. Tobin's Q is the market value of asset divided by the book value of asset. Market Value of asset is the sum of the book value of asset and market value of equity minus the sum of the book value of common equity and balance sheet deferred taxes. Market value of equity is the product of number of shares outstanding and price of the share at the fiscal year end. The data definition is from Kaplan and Zingales 1997.The second entry is the corresponding t statistics. The second entry for the Chow Fisher $T$ test is the corresponding $p$ value. 


\begin{tabular}{|c|c|c|c|c|c|c|c|c|c|}
\hline & \multicolumn{3}{|c|}{ First Tercile } & \multicolumn{3}{|c|}{ Second Tercile } & \multicolumn{3}{|c|}{ Third Tercile } \\
\hline & Pre & Post & Pooled & Pre & Post & Pooled & Pre & Post & Pooled \\
\hline \multicolumn{10}{|c|}{ Panel A: Descriptive Statistics } \\
\hline Mean & $76.88 \%$ & $51.60 \%$ & & $60.14 \%$ & $66.37 \%$ & & $35.73 \%$ & $79.15 \%$ & \\
\hline Mean Difference & -25.2 & & & & & & 43. & & \\
\hline (p value) & $(0.0$ & & & & & & $(0.0$ & & \\
\hline \multicolumn{10}{|c|}{ Panel B: Regression Results } \\
\hline \multirow[t]{2}{*}{ Intercept } & 0.16 & 0.07 & 0.16 & 0.14 & 0.23 & 0.14 & 0.19 & 0.14 & 0.19 \\
\hline & 2.29 & 0.95 & 2.32 & 2.07 & 4.71 & 2.03 & 2.12 & 1.93 & 2.04 \\
\hline \multirow[t]{2}{*}{ Tobin's Q } & 0.05 & 0.13 & 0.05 & 0.13 & 0.14 & 0.13 & 0.09 & 0.07 & 0.09 \\
\hline & 0.72 & 3.43 & 0.73 & 2.15 & 3.48 & 2.11 & 1.27 & 1.82 & 1.22 \\
\hline \multirow[t]{2}{*}{ Cash Flow } & 0.27 & 0.40 & 0.27 & 0.03 & -0.13 & 0.03 & 0.12 & 0.47 & 0.12 \\
\hline & 1.51 & 2.08 & 1.53 & 0.26 & -0.88 & 0.26 & 0.67 & 2.77 & 0.64 \\
\hline \multirow[t]{3}{*}{ Dereg_Dum } & & & -0.10 & & & 0.10 & & & -0.05 \\
\hline & & & -0.97 & & & 1.16 & & & -0.43 \\
\hline & & & 0.13 & & & -0.16 & & & 0.35 \\
\hline
\end{tabular}




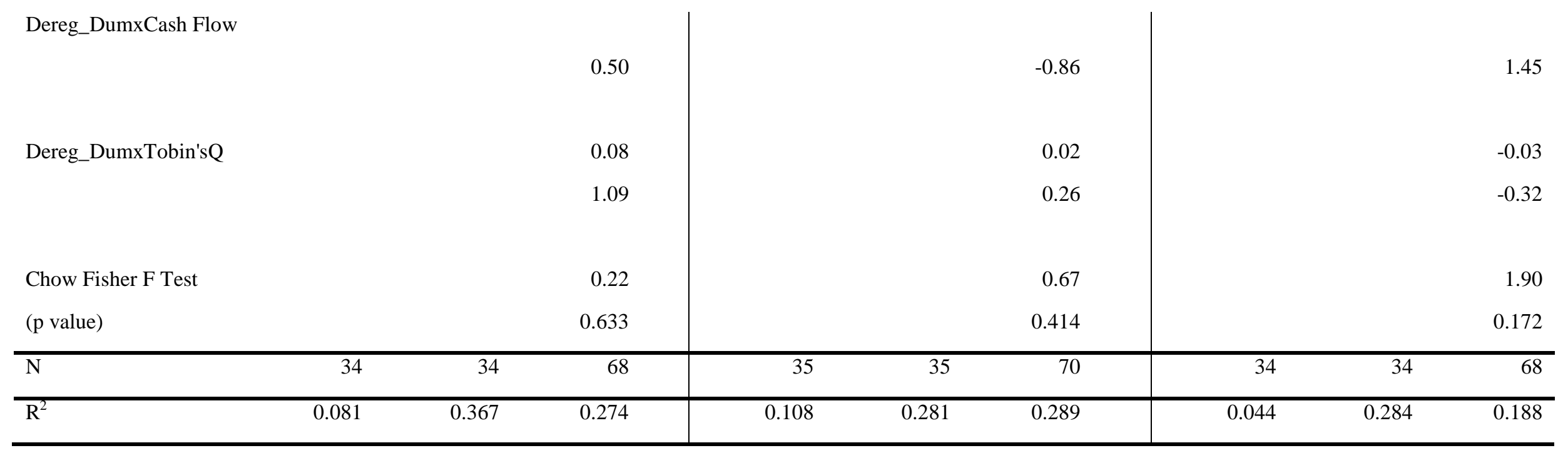

